\title{
High-fluence low-power laser irradiation promotes odontogenesis and inflammation resolution in periodontitis by enhancing stem cell proliferation and differentiation
}

\author{
TIEJUN HOU ${ }^{1}$, SHANYONG LI ${ }^{2}$, GUANGWEI ZHANG ${ }^{2}$ and YAN LI ${ }^{1}$ \\ ${ }^{1}$ Department of Stomatology, Liaocheng People's Hospital; ${ }^{2}$ Department of Stomatology, \\ Liaocheng Third People's Hospital, Liaocheng, Shandong 252000, P.R. China
}

Received January 1, 2018; Accepted July 25, 2018

DOI: $10.3892 / \mathrm{ijmm} .2018 .3804$

\begin{abstract}
Periodontitis can exert a severe impact on the life of patients, and the use of stem cell therapy for this disease is promising. The inflammatory response consequent to periodontitis can promote stem cell proliferation. Activated inflammation triggers inhibitory cytokine secretion, thus reducing inflammation subsequent to stem cell activation. High-fluence low-power laser irradiation (HF-LPLI) has the ability to regulate stem cell function through its effect on inflammation. Thus, the aim of the present study was to examine whether HF-LPLI is able to activate stem cells to promote regeneration in periodontitis by promoting inflammation resolution, as well as to evaluate the underlying mechanism of action if an effect is observed. Stem cells were treated with HF-LPLI following inflammation activation. Reverse transcription-quantitative polymerase chain reaction and EdU assay were used to evaluate cell proliferation and differentiation. Flow cytometry and immunofluorescence were also used to detect the ability of HF-LPLI to regulate the surrounding inflammatory environment. Animal models of periodontal disease were treated with stem cells and HF-LPLI, and regeneration was detected by hematoxylin and eosin staining and in vivo imaging. It was observed that HF-LPLI promoted inflammation resolution by reducing the excessive inflammatory response, and finally stimulated stem cell proliferation and differentiation. Furthermore, in vivo results revealed that stem cells treated with HF-LPLI induced bone regeneration. HF-LPLI stimulated stem cell proliferation and differentiation by promoting inflammation resolution subsequent to stem cell activation, providing a new strategy for the clinical treatment of periodontitis.
\end{abstract}

Correspondence to: Professor Yan Li, Department of Stomatology, Liaocheng People's Hospital, 67 Dongchang West Road, Liaocheng, Shandong 252000, P.R. China

E-mail: 18696798440@163.com

Key words: low-power laser irradiation, stem cells, odontoblasts, inflammation resolution, periodontitis

\section{Introduction}

Periodontitis is a chronic inflammation of supporting tissues caused by specific bacteria adhering to and growing on the surfaces of the teeth, which can even cause dental pulp defects and numerous systemic diseases, including pneumonia and cancer (1-3). Available treatments, such as gingivectomy, orthodontic therapy and periodontal splint fixation, are associated with high recurrence rate and pain $(4,5)$. Recently, stem cell regeneration appears to provide a new direction in the treatment of periodontitis (6). Dental pulp stem cells (DPSCs) and periodontal ligament stem cells (PLSCs) represent the basis for an effective treatment due to their regenerative ability (7). Short treatment time, absence of pain and no recurrence are the most marked advantages of using these stem cells (8-10). However, local inflammation not only blocks the normal physiological cell activities, but also damages the cells (7). Therefore, enhancing the treatment effect associated with the understanding of the mechanism is of utmost importance, while improving the inflamed microenvironment and/or promoting rapid cell proliferation and differentiation may represent potential therapeutic strategies.

Periodontitis is characterized by neutrophils and macrophages (MФs) that infiltrate the tissues surrounding the teeth and mediate inflammation, representing the main reason for the worsening of the microenvironment, causing damage and bone resorption (11). MФs can be divided into M1 and M2, depending on their metabolism (12). M1 secret pro-inflammatory cytokines and chemokines, while $\mathrm{M} 2$ secret cytokines that decrease inflammation, including interleukin (IL)-10 and transforming growth factor (TGF)- $\beta(12,13)$. Previous studies have reported that certain inflammatory factors or a specific local microenvironment promote stem cell proliferation $(14,15)$. Therefore, promoting $\mathrm{M} \Phi$ transformation from $\mathrm{M} 1$ to $\mathrm{M} 2$ can reduce inflammation and achieve a therapeutic effect.

High-fluence low-power laser irradiation (HF-LPLI) serves an important role in regulating cell proliferation, differentiation, apoptosis and other cell physiological activities (16). It has been demonstrated that HF-LPLI can also serve a role in regulating inflammation when used for an appropriated period of time (17). HF-LPLI light sources include the He-Ne laser and the GaAs semiconductor laser. In addition, this technique 
has been reported to promote inflammation resolution, which in turn is associated with myeloperoxidase activity, as well as cyclooxygenase (COX)-1 and COX-2 gene expression (17).

Therefore, in the present study, it was hypothesized that HF-LPLI may also promote inflammation resolution by inducing neutrophil apoptosis and $\mathrm{M} \Phi$ reprogramming subsequent to appropriate inflammation activation of stem cells, as well as consequent improvement of osteogenic differentiation, thereby enhancing the efficacy of stem cell treatment to combat periodontitis. Following in vitro validation of this hypothesis and the associated mechanism of action by several techniques, an animal periodontitis model was designed. Stem cell therapy was used, while HF-LPLI was subsequently administered. Finally, the difference in cell proliferation and osteogenic differentiation was evaluated between the control and experimental groups.

\section{Materials and methods}

DPSC and PLSC isolation, identification and culture. DPSCs were obtained from dental pulp tissue explants. The third molars of adult patients (age, 16-25 years) were obtained from the Department of Stomatology at the Liaocheng People's Hospital (Liaocheng, China). All the patients included were informed of the condition and agreed to participate in the research. Teeth were first cleaned by normal saline containing $3 \%$ antibiotic-antimycotic solution (Gibco; Thermo Fisher Scientific, Inc.), and then sterilized dental fissure burs were used to expose the pulp chamber. Subsequently, dental pulp tissues were dissected into fragments $(<0.5 \mathrm{~mm})$, placed into a 6-cm dish containing Dulbecco's modified Eagle's medium (DMEM; Gibco; Thermo Fisher Scientific, Inc., Waltham, MA, USA) supplemented with $20 \%$ fetal bovine serum (FBS; Gibco; Thermo Fisher Scientific, Inc.) and incubated at $37^{\circ} \mathrm{C}$ with $5 \% \mathrm{CO}_{2}$ for 2-3 weeks. DPSCs were routinely passaged, and third passage cells were used for further experiments. An inverted phase contrast microscope (Nikon Corporation, Tokyo, Japan) was used to observe the cell morphology $(18,19)$.

PLSCs were obtained from teeth from the same hospital. Initially, the tooth was washed by normal saline containing $3 \%$ antibiotic-antimycotic solution (Gibco; Thermo Fisher Scientific, Inc.). Pulp tissues were separated from the surface of the tooth. In total, $1 \mathrm{~g} / \mathrm{l}$ collagenase type I and $2.4 \mathrm{~g} / \mathrm{l}$ dispase (Gibco; Thermo Fisher Scientific, Inc.) were used to digest the tissues for $1 \mathrm{~h}$ at $37^{\circ} \mathrm{C}$. Samples were then centrifuged at $400 \times \mathrm{g}$ for $4 \mathrm{~min}$ at $4^{\circ} \mathrm{C}$ by TD5Z Multi-frame Centrifuge (Jintan Changzhou Instrument Factory, Changzhou, China), and the pellet was collected. Cells were resuspended in DMEM containing 20\% FBS. Cells at the sixth passage were used in subsequent experiments $(20,21)$.

Flow cytometry. DPSCs and PLSCs were identified by flow cytometry. The cell suspension was prepared using an icy buffer (PBS), the cell concentration was adjusted to $5 \times 10^{5}$ cells $/ \mathrm{ml}$. Next, samples were centrifuged at $1,500 \mathrm{x}$ g for $3 \mathrm{~min}$ at $37^{\circ} \mathrm{C}$ and the appropriate fluorescent-labeled antibodies were added to each sample. Anti-STRO-1 antibody was used in DPSCs (cat. no. ab214086; $1 \mu \mathrm{g} / \mathrm{ml}$ ), cluster of differentiation (CD)44 antibody was used in PLSCs (cat. no. ab157107; $1 \mu \mathrm{g} / \mathrm{ml}$ ), and CD133 antibody was used in both cell samples (cat. no. ab19898; $1 \mu \mathrm{g} / \mathrm{ml}$; all purchased from Abcam (Cambridge, MA, USA). Subsequent to antibody addition, the samples were centrifuged at $1,500 \times \mathrm{g}$ for $3 \mathrm{~min}$ at $37^{\circ} \mathrm{C}$, followed by the addition of $0.5 \mathrm{ml}$ formaldehyde and incubated for $24 \mathrm{~h}$ in $-4^{\circ} \mathrm{C}$. Rabbit Anti-Rat IgG H\&L (horseradish peroxidase; cat. no. ab6734; Abcam) was added as seconded antibody and incubated for $8 \mathrm{~h}$ in $-4^{\circ} \mathrm{C}$. Samples were kept at $4^{\circ} \mathrm{C}$ until the end of the experimental analysis. Flow cytometry (BD LSRFortessa $^{\mathrm{TM}}$ cell analyzer; BD Biosciences, San Jose, CA, USA) was finally used to identify the cells (18-21).

The two types of stem cells were cultured into 6-wells plates $\left(5 \times 10^{4}\right.$ cells/well). Cells were divided into four groups, including the control, M $\Phi, M \Phi+H F-L P L I$, and the $M \Phi$ followed by HF-LPLI groups. In these groups, the concentration of $\mathrm{M} \Phi$ was $1 \times 10^{4}$ cells/well. In the $\mathrm{M} \Phi$ group, the cells were co-cultured with MФ for $6 \mathrm{~h}$ and without HF-LPLI treated. In the M $\Phi+H F-L P L I$ group, stem cells were treated with HF-LPLI and simultaneously co-cultured with $М \Phi$. In the M $\Phi$ followed by HF-LPLI group, stem cells were treated with HF-LPLI subsequent to co-culturing with MФ for $6 \mathrm{~h}$.

Neutrophil and $M \Phi$ isolation and culture. Male Sprague Dawley (SD) rats (age 6-8 weeks old, 250-280 g, $\mathrm{n}=10$ ) were obtained from the Laboratory Animal Center of Taishan Medical University (Taian, China). SD rats were cultured in $37^{\circ} \mathrm{C}$, relative humidity $45 \%$ and 12 -h light/dark environment with low fat diet and free to water. The rats were then subjected to an intraperitoneal injection of $1 \mathrm{ml} \mathrm{4 \%}$ thioglycollate (Guangzhou SWAN Chemical Co., Ltd., Guangzhou, China; cat. no. 2365-48-2). After 24 h, $10 \mathrm{ml}$ cold Dulbecco's phosphate-buffered saline containing $100 \mathrm{U} / \mathrm{ml}$ penicillin was injected into the peritoneum. Peritoneal lavage fluids were mixed thoroughly and collected. Neutrophils from the fluid were spun and re-suspended with pre-warmed serum-free RPMI-1640 medium containing $0.05 \%$ bovine serum albumin (WelGENE, Inc., Pohang, Korea). Cells were plated into a 6 -well plate ( $5 \times 10^{6}$ cells/well) (22), and divided into the control and lipopolysaccharide (LPS) group for apoptosis detection by flow cytometry. In the LPS group, cells were cultured in medium containing $1 \mu \mathrm{g} / \mathrm{ml}$ LPS (Sigma-Aldrich; Merck KGaA, Darmstadt, Germany) which was used to create an inflammatory culture condition.

Rat MФs were purchased from the Shanghai Institutes for Biological Sciences of the Chinese Academy of Sciences (Shanghai, China). Cells were cultured in RPMI-1640 medium (WelGENE, Inc.) containing 10\% FBS, $100 \mathrm{U} / \mathrm{ml}$ penicillin and $100 \mu \mathrm{g} / \mathrm{ml}$ streptomycin, followed by plating in a 6 -well plate $\left(4 \times 10^{6}\right.$ cells/well) and incubation at $37^{\circ} \mathrm{C}$ in $5 \% \mathrm{CO}_{2}$ for $48 \mathrm{~h}$. МФs were divided into three groups, including the control, LPS and HF-LPLI groups, for immunofluorescence detection. In the HF-LPLI group, HF-LPLI treatment was applied following $1 \mu \mathrm{g} / \mathrm{ml}$ LPS incubation for $24 \mathrm{~h}$.

HF-LPLI application. In the present study, a He-Ne laser with output power at $632.8 \mathrm{~nm}$ and a $10.5-\mathrm{mW}$ red laser were used for HF-LPLI application. For in vitro experiments, samples were directly treated under $20 \mathrm{~J} / \mathrm{cm}^{2} \mathrm{HF}$-LPI for $1 \mathrm{~h}$. Furthermore, oral radiation was performed by optical fiber, $20 \mathrm{~J} / \mathrm{cm}^{2}$ for $1 \mathrm{~h}$ to the first molars and their periodontal tissue with other teeth covered by aluminum foil paper (16). 
Apoptosis detection by flow cytometry. Neutrophils and MФs cultured in vitro were divided into the control and LPS groups. The supernatant of cells was collected into a $15 \mathrm{ml}$ centrifuge tube. EGTA-free trypsin was added to digest the neutrophils, and trypsin was added to the corresponding centrifuge tube. Next, PBS was added to wash down the cells attached on the tube. Samples were centrifuged at 1,000 x $\mathrm{g}$ for $3 \mathrm{~min}$, and then PBS was used to wash the cells twice, following by further centrifugation at $1,000 \mathrm{x} g$ for $3 \mathrm{~min}$. Subsequently, Annexin V was added according to the manufacturer's protocol described in the FITC Annexin V Apoptosis Detection kit (BD Biosciences). Flow cytometry (BD LSRFortessa ${ }^{\mathrm{TM}}$ cell analyzer; BD Biosciences) was finally used to evaluate apoptosis (23-25).

Caspase-3 activity analysis. The caspase-3 activity of neutrophils was detected by a Caspase-3 Activity Assay kit (Beyotime Institute of Biotechnology, Haimen, China) according to the manufacturer's protocol. Briefly, samples at $0,2,4$ and $6 \mathrm{~h}$ following HF-LPLI treatment were ground and then incubated in lysis buffer on ice for $15 \mathrm{~min}$. The mixture was centrifuged at $16,000 \mathrm{x} \mathrm{g}$ for $10 \mathrm{~min}$ at $4^{\circ} \mathrm{C}$, followed by the addition of 2 mmol Ac-DEVD-pNA (Sigma-Aldrich; Merck KGaA) for $1 \mathrm{~h}$. Absorbance was measured at $405 \mathrm{~nm}$ using a microplate reader (Thermo Fisher Scientific, Inc.). The caspase-3 activity of each sample was calculated according to the standard curve and normalized to the total protein concentration $(26,27)$.

Immunofluorescence analysis. MФs were seeded into 6-well plates at a density of $5 \times 10^{4}$ per well and incubated for $48 \mathrm{~h}$, and then were washed three times with PBS, fixed with $4 \%$ paraformaldehyde for $15 \mathrm{~min}$ and subsequently treated with $0.5 \%$ Triton $\mathrm{X}-100$ for $20 \mathrm{~min}$ at room temperature. Sufficient dilution of primary polyclonal anti-rat CD86 (cat. no. MA110293; 1:1,000) or CD163 (cat. no. AB-2716934; 1:1,000) antibodies against M1 and M2 (Thermo Fisher Scientific, Inc.) was added to each slide, and incubated overnight at $4^{\circ} \mathrm{C}$. The slides were washed three times with PBS/Tween-20 for 3 min each time and then treated with secondary antibodies at $20-37^{\circ} \mathrm{C}$ in the dark for $1 \mathrm{~h}$. Next, samples were incubated with DAPI (Beyotime Institute of Biotechnology) for $5 \mathrm{~min}$. Slides were dried using an absorbent paper, mounted with liquid sealing agents containing anti-fluorescence quenching reagents and observed under a fluorescent microscope for image acquisition $(28,29)$.

NO concentration detection. DAF-FM DA (Beyotime Institute of Biotechnology) was used to detect the NO concentration in adherent neutrophils. DAF-FM DA was diluted to 1:1,000 using the dilution buffer provided in the kit. Next, samples were incubated in an incubator for $20 \mathrm{~min}$. Cells were collected, treated with $5 \mu \mathrm{mol} / 1 \mathrm{DAF}-\mathrm{FM} \mathrm{DA}$, incubated at $37^{\circ} \mathrm{C}$ for $20 \mathrm{~min}$ and subjected to flow cytometry analysis (30).

A total of 7 scalp needles were used to draw blood from the caudal vein of the SD rats, then centrifuged $2,000 \mathrm{xg}$ for $2 \mathrm{~min}$ at $37^{\circ} \mathrm{C}$ to obtain the rat serum. In order to detect the NO concentration in the rat serum, a Nitric Oxide Assay kit (Sigma-Aldrich; Merck KGaA) was used. The assay was conducted according to the protocol provided in the kit, and NO was measured using the Thermo Scientific ${ }^{\mathrm{TM}}$ SPECTRONIC ${ }^{\mathrm{TM}} 200$ spectrophotometer (Thermo Fisher Scientific, Inc.) (31).
Reverse transcription-quantitative polymerase chain reaction (RT-qPCR) analysis. RT-qPCR was used to evaluate if DPSCs and PLSCs maintained stem cell properties and osteogenesis differentiation using the GoTaq $^{\circledR}$ qPCR Master Mix, Promega A60021000 Reactions (Promega Corporation, Madison, WI, USA). Cells were digested by TRIzol RNA separation reagent (Thermo Fisher Scientific, Inc.). The RNA concentration was determined by ultraviolet spectrophotometer. DEPC $\mathrm{H}_{2} \mathrm{O}$ was used to zero instrument, it's also used to dilute RNA. The absorbance of RNA in $260 \mathrm{~nm}$ (A260) was tested. The analytical formula of RNA concentration is A260X dilution multiple $\mathrm{x} 40 \mu \mathrm{g} / \mathrm{ml}$. qPCR reaction was then performed in a thin wall $0.5-\mathrm{ml}$ reaction tube, and the mixture consisted of $13.5 \mu \mathrm{l}$ DEPC water, $2 \mu \mathrm{l}$ dNTP Mix, $1 \mu \mathrm{l}$ oligo(dT) 12-18, $1 \mu \mathrm{l} \mathrm{AMV/Tfl} 5 \mathrm{X}$ reaction buffer, $0.5 \mu \mathrm{l}$ RNase inhibitor, $1 \mu \mathrm{l}$ AMV-RT reverse transcriptase. Firstly, samples were incubated at $42^{\circ} \mathrm{C}$ for $1 \mathrm{~h}, 95^{\circ} \mathrm{C}$ for $5 \mathrm{~min}$, the cDNA templates were produced. Secondly, $10 \mu \mathrm{l}$ cDNA tempaltes, $10 \mu 1$ 2Xtap mix, $31.5 \mu \mathrm{l}$ DEPC water, $1 \mu \mathrm{l} \mathrm{dNTP}$ Mix, $2 \mu \mathrm{l}$ specific upstream and downstream primers of the target genes, including Sox2, Oct4, Klf4, ALP, OCN and Runx2 (Table I), $5 \mu 1$ 10X buffer and $0.5 \mu \mathrm{l}$ DNA polymerases were add to a new PCR tubes. The PCR thermal cycling conditions were: $95^{\circ} \mathrm{C}(5 \mathrm{~min}), 95^{\circ} \mathrm{C}$ $(1 \mathrm{~min}), 55^{\circ} \mathrm{C}(90 \mathrm{sec}), 72^{\circ} \mathrm{C}(90 \mathrm{sec})$ at $72^{\circ} \mathrm{C}$ and $(10 \mathrm{~min})$ at $4^{\circ} \mathrm{C}$. The number of cycles (step 2-step 4) was 30. A total of $10 \mu 1$ PCR product was detected by $0.5 \%$ agarose gel electrophoresis. Agarose gel electrophoresis was used to analyze the PCR products observed under UV light. Analysis of relative gene expression data using the $2^{-\Delta \Delta \mathrm{Cq}}$ method (32-34).

EdU assay. In order to detect the proliferation and vitality of cells, Click-iT ${ }^{\mathrm{TM}}$ EdU Flow Cytometry Assay kit (Alexa Fluor $^{\mathrm{TM}}$ 488; Thermo Fisher Scientific, Inc.) was used according to the manufacturer's protocol. Briefly, cells were washed three times in PBS containing $0.05 \%$ Triton X-100 prior to EdU-DNA detection. For nuclear staining (blue), stem cell samples were treated with $1 \mu \mathrm{g} / \mathrm{ml}$ DAPI in PBS containing $0.1 \%$ Triton X-100. Next, the samples were incubated for $1 \mathrm{~h}$ at $37^{\circ} \mathrm{C}$ in the dark. Newly proliferating nucleotides were stained red by $2 \mathrm{X}$ EdU solution according to the manufacturer's protocol. Then, the samples were visualized under a fluorescence inverted microscopy (VMF400I, Suzhou Jing Tong Instrument Co., Ltd. Suzhou, China) (35-37).

ELISA. The MФ supernatant was collected from the three MФ groups cultured in vitro, including the control, LPS and HF-LPLI cell groups. In addition, serum samples from the hearts of rats in the control, periodontitis, and 1 or 3 -week HF-LPLI treatment groups were obtained by 2,000 x $\mathrm{g}$ for $15 \mathrm{~min}$ at $37^{\circ} \mathrm{C}$. Subsequently, $100 \mu \mathrm{l}$ Standards and $100 \mu \mathrm{l}$ samples were added into the corresponding reaction plate well. Subsequent steps were conducted according to the protocol provided by the MitoBiogenesis ${ }^{\mathrm{TM}}$ In-Cell ELISA kit (Colorimetric; cat. no. ab110217; Abcam). Finally, the optical density was measured at $450 \mathrm{~nm}(38,39)$.

Alizarin red $S$ staining. For the evaluation of osteogenesis differentiation, local tissues obtained from the animal model were washed twice with PBS, fixed with $10 \%$ formaldehyde for $20 \mathrm{~min}$ and washed twice with PBS. Cells were treated with 
Table I. Primers used in quantitative polymerase chain reaction.

\begin{tabular}{|c|c|c|c|c|}
\hline Target gene & Primer sequence & Annealing temperature $\left({ }^{\circ} \mathrm{C}\right)$ & Cycles & Product size (bp) \\
\hline \multirow[t]{2}{*}{ Oct 4} & F: 5'-CAGTGCCCGAAACCCACAC-3' & & & \\
\hline & R: 5'-GGAGACCCAGCAGCCTCAAA-3' & 60 & 40 & 161 \\
\hline \multirow[t]{2}{*}{ Sox 2} & F: 5'-ACACCAATCCCATCCACACT-3' & & & \\
\hline & R: 5'-GCAAACTTCCTGCAAAGCTC-3' & 60 & 40 & 224 \\
\hline \multirow[t]{2}{*}{ Klf4 } & F: 5'-GAGCCCAAGCCAAAGAGG-3' & & & \\
\hline & R: 5'-ATCCACAGCCGTCCCAGT C-3' & 60 & 40 & 183 \\
\hline \multirow[t]{2}{*}{ ALP } & F: 5'-CCACGTCTTCACATTTGGTG-3' & & & \\
\hline & R: 5'-AGACTGCGCCTGGTAGTTGT-3' & 60 & 40 & 196 \\
\hline \multirow[t]{2}{*}{ OCN } & F: 5'-GGCAGCGAGGTAGTGAAGAG-3' & & & \\
\hline & R: 5'-CTGGAGAGGAGCAGAACTGG-3' & 60 & 40 & 230 \\
\hline \multirow[t]{2}{*}{ Runx2 } & F: 5'-CCCGTGGCCTTCAAGGT-3' & & & \\
\hline & R: 5'-CGTTACCCGCCATGACAGTA-3' & 60 & 40 & 179 \\
\hline \multirow[t]{2}{*}{ GAPDH } & F: 5'-GGGAAACTGTGGCGTGAT-3' & & & \\
\hline & R: 5'-GAGTGGGTGTCGCTGTTGA-3' & 60 & 40 & 299 \\
\hline
\end{tabular}

F, forward; R, reverse.

$40 \mathrm{mM}$ alizarin red S solution (Sigma-Aldrich; Merck KGaA) for $20 \mathrm{~min}$ at room temperature. Finally, samples were washed with distilled water for four times for further evaluation under a microscope (40).

Animal experiment. Male SD rats (age 6-8 weeks old, 250-280 g) were obtained from the Laboratory Animal Center in Taishan Medical University ( $\mathrm{N}=24$ in total, $\mathrm{n}=8$ for a group). SD rats were housed at $37^{\circ} \mathrm{C}$, relative humidity $45 \%$ and dark environment with low fat diet and free to water. All animal procedures were performed according to the Guide for the Care and Use of Laboratory Animals (18), following the ARRIVE guidelines (41), and were approved by the Institutional Clinical Experiments Committee of the Liaocheng People's Hospital (Liaocheng, China) and the Animal Care Committee. Rats were divided into three groups of 8 rats each, including the control, periodontitis and HF-LPLI groups. Subsequent to gingival peeling and high-sugar feeding, all rats received azithromycin $(10 \mathrm{mg} / 500 \mathrm{ml}$; Shanghai Yingrui Biopharma Co., Ltd., Shanghai, China) for 4 days, followed by a 7-day antibiotic-free period. Next, rats were anesthetized with $10 \%$ chloral hydrate. A $0.2-\mathrm{mm}$ wire was placed in the dentogingival area of both mandibular first molars in the periodontitis and HF-LPLI groups for $48 \mathrm{~h}$, while the wire was placed and immediately removed in the control group. All rats were fed with the same food (at 8:00 a.m. and 8:00 p.m.). Rats in the HF-LPLI groups underwent surgery, followed by a 1-week $20-\mathrm{J} / \mathrm{cm}^{2} \mathrm{HF}-\mathrm{LPLI}$ treatment for $1 \mathrm{~h} /$ day after local injection of $1 \times 10^{5} / \mathrm{ml}$ stem cells in $100 \mu \mathrm{l}$, followed by the in vivo bioluminescence imaging and H\&E staining $(42,43)$. The Height of bone regeneration was calculated as $8 \mathrm{~mm}-(\mathrm{a} 1+\mathrm{a} 2+\mathrm{a} 3) / 3$. In the formula, a1, a 2 and a 3 were three random height measurements of residual defect height following bone regeneration.

In vivo bioluminescence imaging. SD rats were divided into three groups, including the control (6 weeks),HF-LPLI/6-week and HF-LPLI/12-week groups, and were analyzed at the corresponding time point. Rats were anesthetized with $10 \%$ chloral hydrate and treated with fluorescein that was injected through the tail vein. At 60 min post-infection images were obtained after intraperitoneal injection of D-luciferin (150 mg/kg body weight; Thermo Fisher Scientific, Inc.), followed by $50 \mu \mathrm{l} \mathrm{D}$-luciferin $(0.75 \mathrm{mg}$ in PBS) through the oral cavity. The IVIS Lumina image system (Xenogen Corporation, Alameda, CA, EUA) was used to capture the images (44).

Hematoxylin and eosin $(H \& E)$ staining. Periodontal tissue $\sim 200 \times 200 \mu \mathrm{m}$ fragments from the animal model were dewaxed by xylene, washed with an alcohol gradient and then soaked in distilled water. Next, tissues were stained with Harris hematoxylin solution for $5 \mathrm{~min}$. Subsequent to rinsing, sections underwent color separation in $0.5 \%$ hydrochloric-alcohol solution for $5 \mathrm{sec}$, followed by washing two times with $95 \%$ ethyl alcohol for $5 \mathrm{~min}$ each, two times with absolute ethyl alcohol for $5 \mathrm{~min}$ each and xylene + ethyl alcohol (1:1) for $5 \mathrm{~min}$. Finally, samples were subjected to xylene cleaning and neutral gum sealing, and followed by visualization under light microscope (Nikon Corporation, Tokyo, Japan) (35-37).

Statistical analysis. Statistical analysis was performed using the SPSS software package (version 13; SPSS, Inc., Chicago, IL, USA). The results are expressed as the mean \pm standard deviation, and the analysis of variance test was used to evaluate the statistical significance between two groups. $\mathrm{P}<0.05$ was considered to indicate a statistically significant when the.

\section{Results}

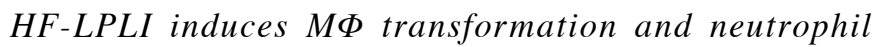
apoptosis. The inflammatory reaction is one of the causes of 


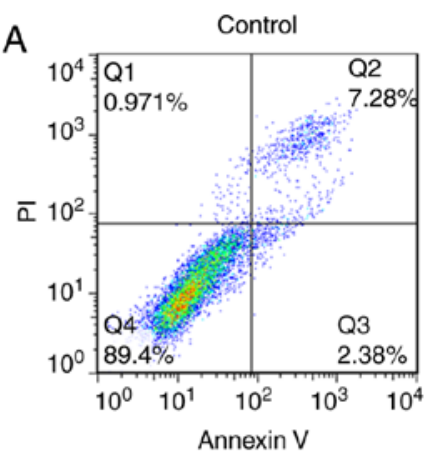

C

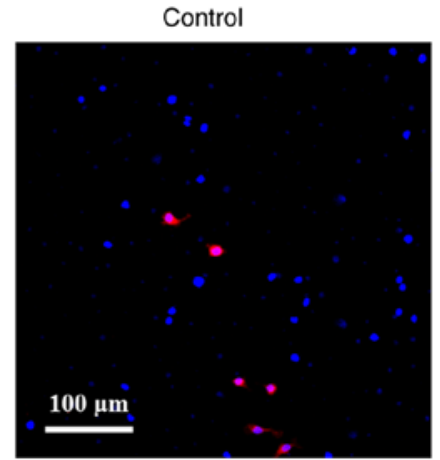

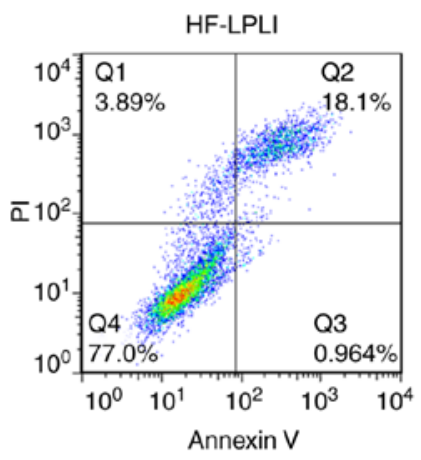

LPS
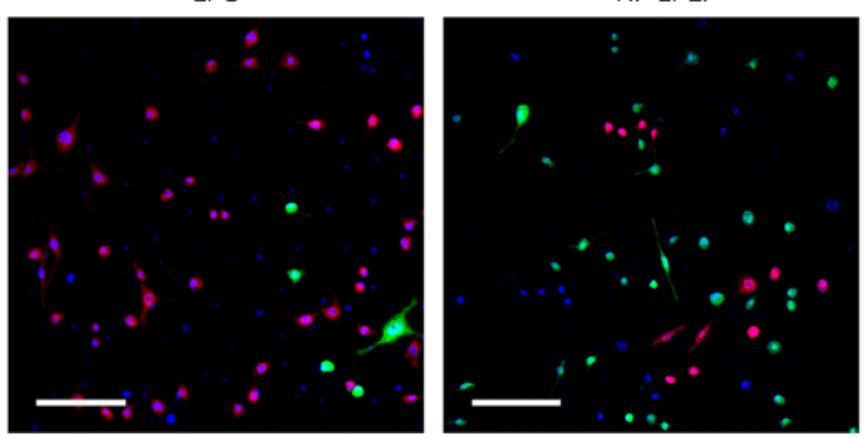
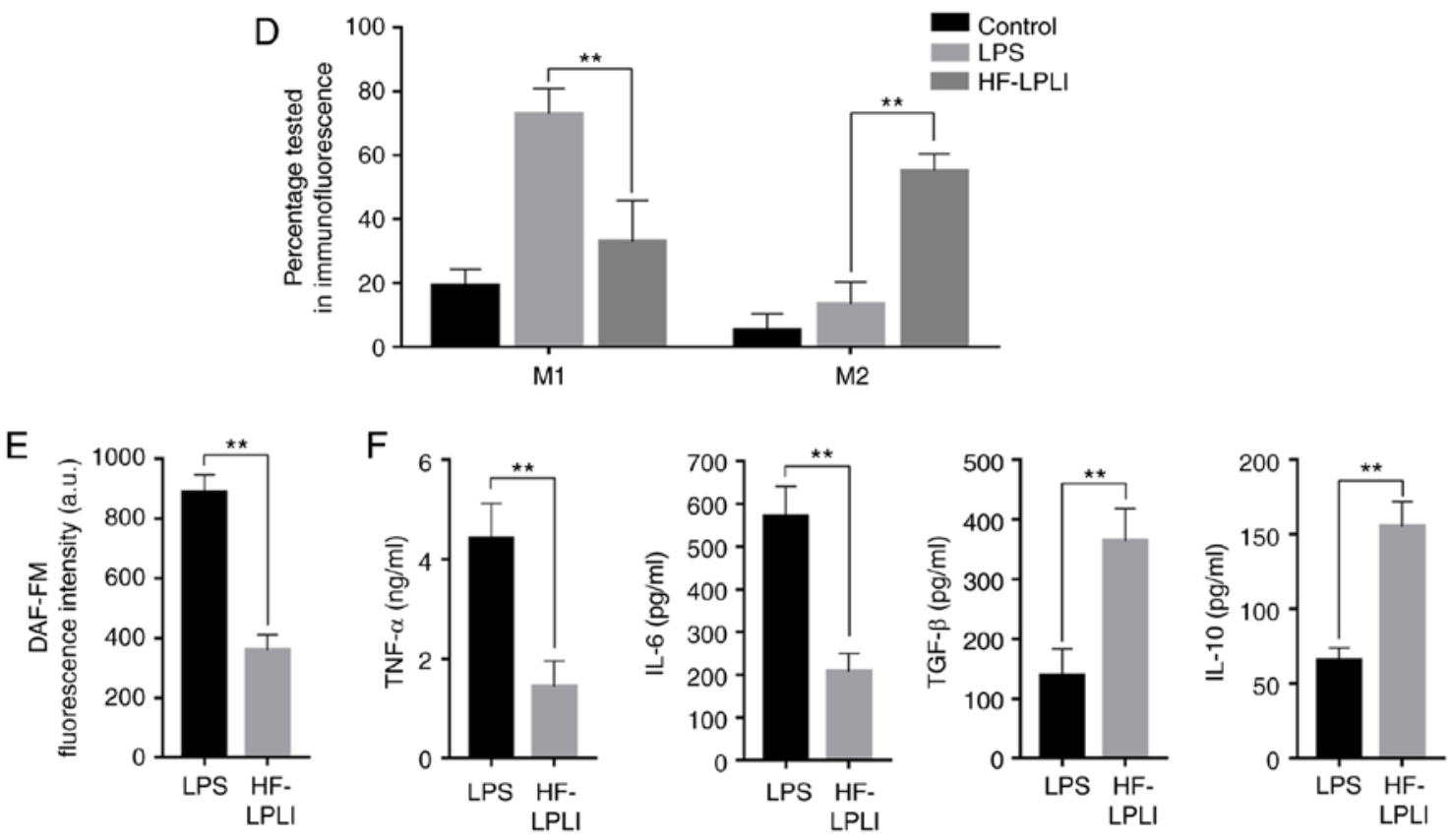

Figure 1. HF-LPLI promoted neutrophil apoptosis and MФ reprogramming, and inhibited the release of inflammatory factors. (A) Apoptosis of HF-LPLI-treated neutrophils was detected by flow cytometry. (B) Apoptosis activation in neutrophils, detected by caspase-3 activity assay. (C) CD86 and CD163 immunofluorescent staining using red and green fluorophores, respectively, and nuclei stained with DAPI (scale bar, $100 \mu \mathrm{m}$ ). (D) Bar graph of CD86- and CD163-positive MФ percentage by immunofluorescent staining. (E) NO concentration examined by DAF-FM DA. (F) Concentration of inflammatory factors, including TNF- $\alpha$, IL- 6 , IL-10 and TGF- $\beta$, determined by ELISA. The results are representative of 10 independent experiments, and are expressed as the mean \pm standard deviation. ${ }^{* *} \mathrm{P}<0.01$ vs. LPS group $(\mathrm{n}=10)$. HF-LPLI, high-frequency low-power laser irradiation; M $\Phi$, macrophage; TNF- $\alpha$, tumor necrosis factor $\alpha$; IL, interleukin; TGF- $\beta$, transforming growth factor- $\beta$; LPS, lipopolysaccharide.

periodontal tissue damage. The results of the present study revealed that HF-LPLI promoted inflammation resolution in vitro by promoting neutrophil apoptosis and $\mathrm{M} \Phi$ reprogramming. Flow cytometry demonstrated that cells obtained and labeled by STRO-1 and CD 44 were the DPSCs and PLSCs we wanted (data not shown). Furthermore, it also demonstrated neutrophil apoptosis increased subsequent to HF-LPLI treatment, ranging between 7.28 and 18.1\% (Fig. 1A). In addition, HF-LPLI induced a time-dependent increase of caspase-3 activation, which was $2.8 \pm 0.17$ times higher than the initial value at $6 \mathrm{~h}$ (Fig. 1B). This further demonstrated the role of HF-LPLI in promoting apoptosis. In fact, the MФ 

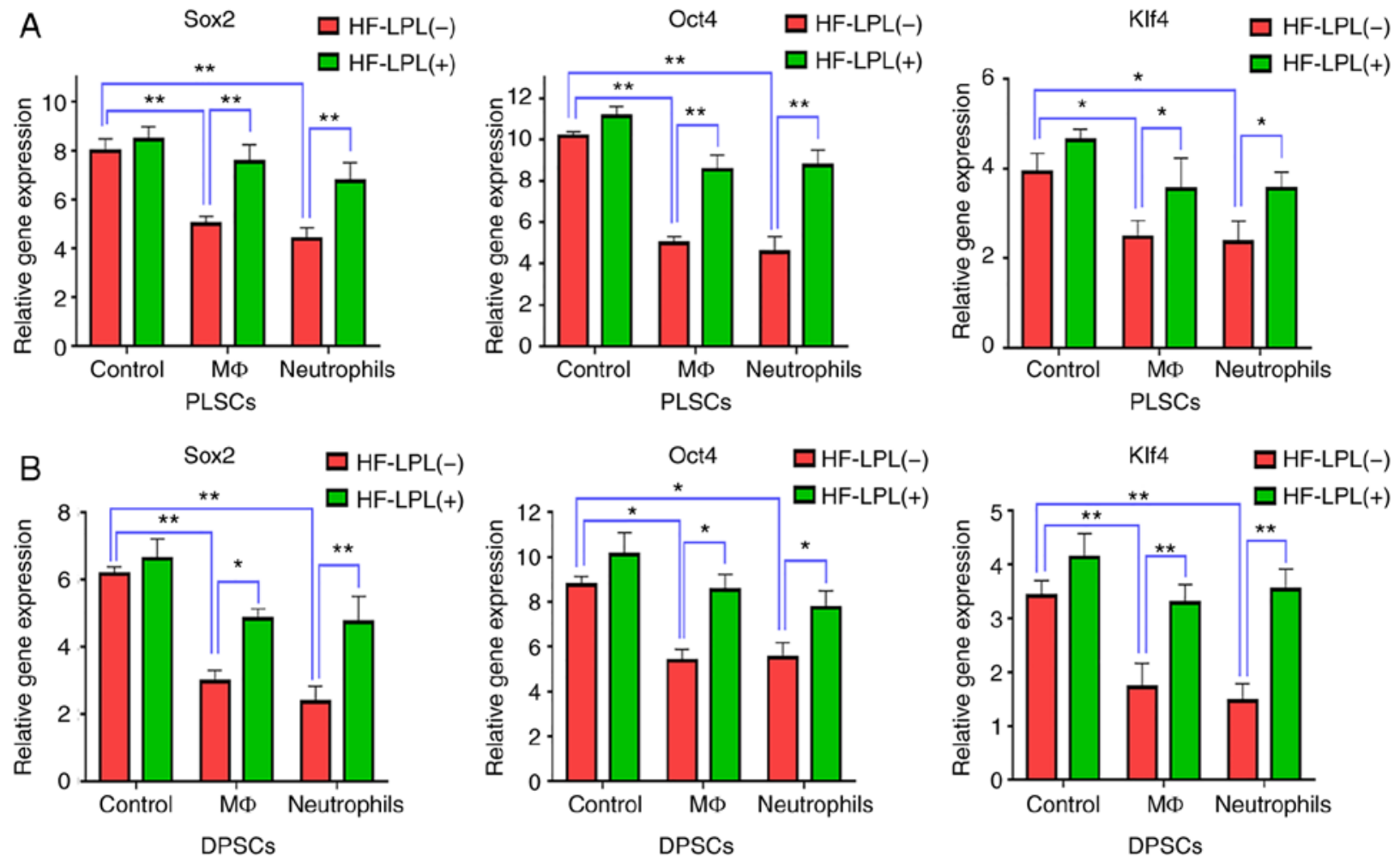

Figure 2. HF-LPLI maintained the stemness of PLSCs and DPSCs. Sox, Oct4 and Klf4 expression levels in (A) PLSCs and (B) DPSCs in the control and experimental groups, as examined by reverse transcription-quantitative polymerase chain reaction. ${ }^{*} \mathrm{P}<0.05$ and ${ }^{* * *} \mathrm{P}<0.01$. HF-LPLI, high-frequency low-power laser irradiation; MФ, macrophage; PLSC, periodontal ligament stem cell; DPSC, dental pulp stem cell.

apoptosis was also tested following HF-LPLI treatment, and the results indicated that HF-LPLI had no effect on MФ apoptosis (data not shown). In the pre-experiments, it was observed that $6 \mathrm{~h}$ was the best time period for inflammation to promote the function of stem cells (data not shown). In the tests conducted in the present study, all the related experimental design selected inflammation treatment to last $6 \mathrm{~h}$ (data not shown). Immunofluorescence analysis detected no significant differences in the morphology of different types of MФs, while the reprogramming of MФs was confirmed. The LPS group exhibited an increase in the number of CD86-M1 (red staining), while the HF-LPLI-treated group mainly exhibited green staining, corresponding to CD163-M2 (Fig. 1C). Following HF-LPLI treatment, the number of CD86-M1 decreased from $73.21 \pm 2.23 \%$ to $18.29 \pm 1.47 \%$ ( $\mathrm{P}<0.05)$, while CD163-M2 increased from $9.26 \pm 1.07 \%$ to $58.88 \pm 1.97 \%$ (Fig. 1D). In addition, DAF-FM IL-6 and tumor necrosis factor $\alpha(\mathrm{TNF}-\alpha)$ levels significantly decreased following HF-LPLI treatment, while the levels of anti-inflammatory cytokines, including IL-10 and TGF- $\beta$, secreted by M2 were increased (Fig. 1E and F).

HF-LPLI maintains the stem cell properties of DPSCs and PLSCs. RT-qPCR was used to detect the mRNA expression levels of genes associated with the reprogramming of stem cells, including Sox2, Oct4 and Klf4, prior to and following HF-LPLI treatment. The results indicated that Sox2, Oct4 and Klf4 expression levels in DPSCs and PLSCs in the control group treated with HF-LPLI slightly increased as compared with those in cells without HF-LPLI treatment, although a significant difference was not observed $(\mathrm{P}>0.05$; Fig. 2A and B). When stem cells were co-cultured with MФs or neutrophils, the expression of these three genes was significantly decreased $(\mathrm{P}<0.05)$, while HF-LPLI treatment inhibited this effect and increased the gene levels. More specifically, Oct4 expression in PLSCs was decreased to a value of $4.3 \pm 0.2$ and $4.2 \pm 0.2$ when stem cells were co-cultured with MФs or neutrophils, respectively, while this level was $10.2 \pm 0.3$ in the culture of stem cells without inflammatory cells, and HF-LPLI treatment was able to raise this level to $6.0 \sim 8.0 \pm 0.4$ to a value of $<3$ (Fig. 2A). In DPSCs, inflammatory cells exhibited a marked effect on Sox 2 expression, which was decreased from $6.2 \pm 0.4$ to a value of $<3$. However, HF-LPLI attenuated this effect, increasing the Sox 2 expression to $\sim 5$ (Fig. 2B).

HF-LPLI improves DPSC and PLSC proliferation. EdU assay results demonstrated that stem cell proliferation was not evident when these cells were cultured alone, while their proliferation was evident when co-cultured with MФs. When stem cells were co-cultured with $\mathrm{M} \Phi$ s and simultaneously treated with HF-LPLI, the HF-LPLI treatment did not increase the promotion of stem cell proliferation induced by inflammatory cells. However, after co-culture for $6 \mathrm{~h}$ followed by treatment with HF-LPLI, the stem cell proliferation was greatly improved, as shown by the EdU results (Fig. 3A), and the difference with the other experimental groups and the control group was statistically significant $(\mathrm{P}<0.05)$. The number of EdU-positive cells in the M $\Phi$ group was $13 \pm 1$ and $19 \pm 1$ for DPSCs and PLSCs, respectively, while the number of cells was $5 \pm 1$ and $6 \pm 1$ in 
A
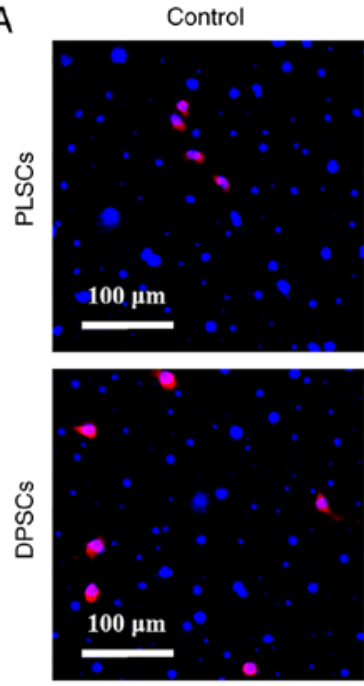

B

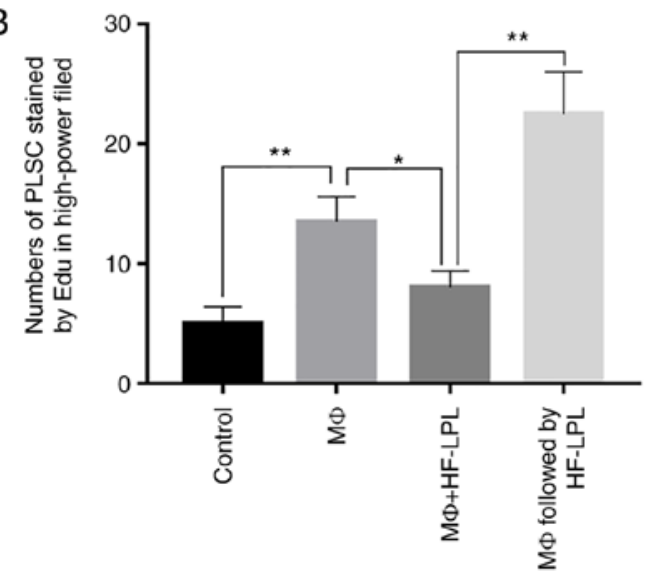

$M \Phi$
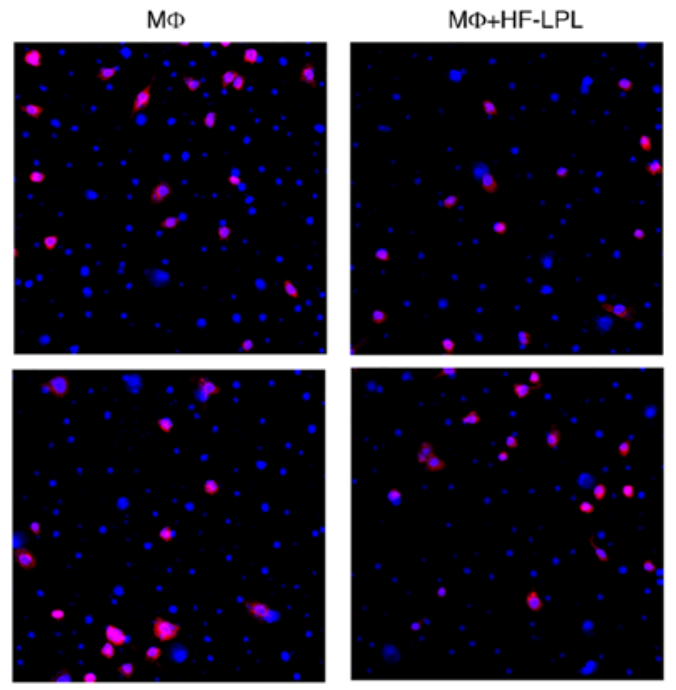

MФ followed by HF-LPL
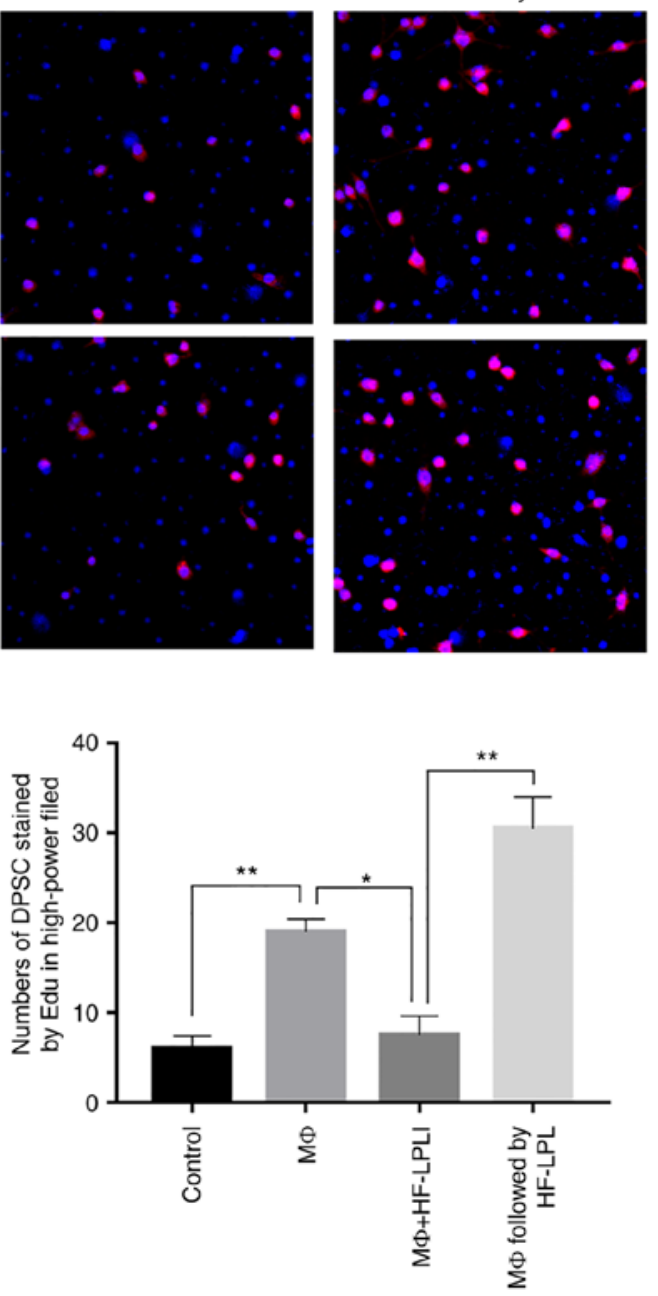

Figure 3. HF-LPLI improved stem cell proliferation. (A) Cell nuclei were stained blue by DAPI, and newly proliferating nucleotides were stained red by EdU in PLSCs and DPSCs (scale bar, $100 \mu \mathrm{m}$ ). (B) Bar graph of stem cell proliferation as determined by EdU assay. *P<0.05 and ** P<0.01. HF-LPLI, high-frequency low-power laser irradiation; MФ, macrophage; PLSC, periodontal ligament stem cell; DPSC, dental pulp stem cell.

the control group, respectively. When HF-LPLI treatment was performed simultaneously with the $\mathrm{M} \Phi$ co-culture in the stem cells, the number of EdU-positive cells was $8 \pm 1$ or $7 \pm 1$ for DPSCs and PLSCs, respectively. However, the number of proliferating cells was $21 \pm 2$ or $29 \pm 2$, respectively, when HF-LPLI treatment was performed at $6 \mathrm{~h}$ after $\mathrm{M} \Phi$ co-culture (Fig. 3B).

HF-LPLI promotes DPSC odontoblastic differentiation. The present study next focused on the establishment of the HF-LPLI ability to induce cell differentiation. ALP, OCN and Runx 2 gene expression levels were evaluated in cells obtained after 2 weeks of proliferation, as described earlier. The results demonstrated that the relative expression levels of the three genes in the $М \Phi$ group were significantly increased to $\sim 2-3 \pm 0.2(\mathrm{P}<0.05$; Fig. 4A). However, gene expression was inhibited to nearly $1.3 \pm 0.2$ when co-culture with $\mathrm{M \Phi s}$ and HF-LPLI treatment were performed simultaneously, while gene expression was promoted when HF-LPLI was performed after $6 \mathrm{~h}$ of $\mathrm{M} \Phi$ co-culture. In addition, OCN expression in DPSCs reached $4.7 \pm 0.8$ (Fig. $4 \mathrm{~A}$ ).

Stem cells in the different M $\Phi$ and HF-LPLI groups were then subjected to alizarin red S staining to identify the calcium salt components in the cells. A significant increase in the calcium ion composition was found in the $М \Phi$ followed by HF-LPLI treatment group (Fig. 4B). For alizarin red $\mathrm{S}$ staining, the absorbance at $570 \mathrm{~nm}$ was $\sim 0.6$ at 2 weeks and 0.9 at 4 weeks in the group with $\mathrm{M} \Phi$ co-culture followed by HF-LPLI treatment, while it was $<0.5$ in the control and M $\Phi$ co-culture alone groups (Fig. 4C).

HF-LPLI reduces the infiltration of inflammatory cells and release of inflammatory factors in periodontitis rats. A large number of neutrophils and $\mathrm{M} \Phi$ s were detected in the inflammatory sites in periodontitis rats during immunofluorescence analysis. After 1 week of HF-LPLI treatment, the number of neutrophils and $\mathrm{M} \Phi$ s in the surrounding tissues decreased significantly from $131 \pm 6$ and $119 \pm 5$ to $44 \pm 3$ and $52 \pm 4$, respectively. After 3 weeks of detection, further improvement in the number of inflammatory cells was achieved, which were inhibited to $9 \pm 2$ and $11 \pm 2$, respectively. CD11b-labeled neutrophils and CD86-labeled MФs were abundant in the surrounding tissues of periodontitis rats, while HF-LPLI application significantly decreased the staining for the inflammatory cells. Furthermore, this effect was found to be enhanced with time (Fig. 5A and B). 

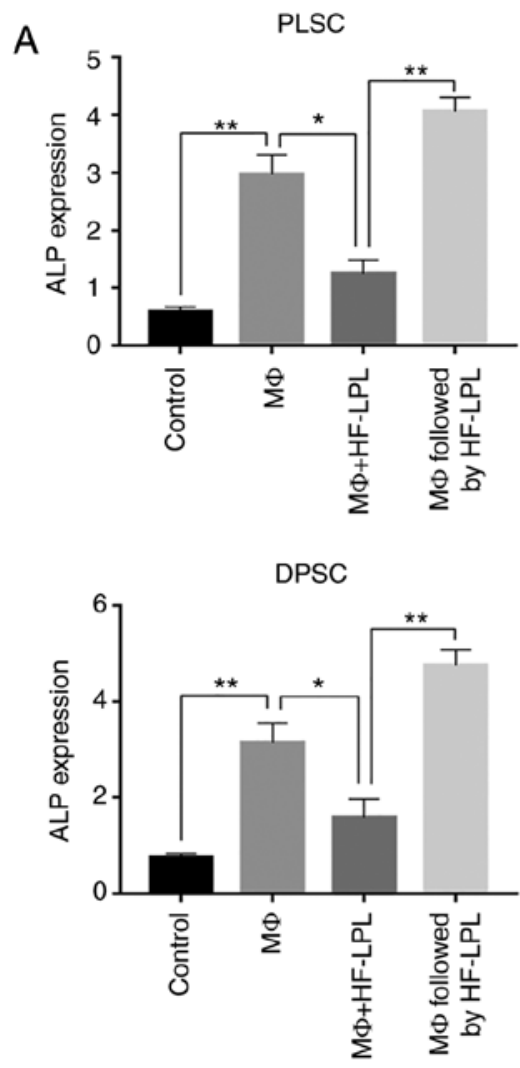

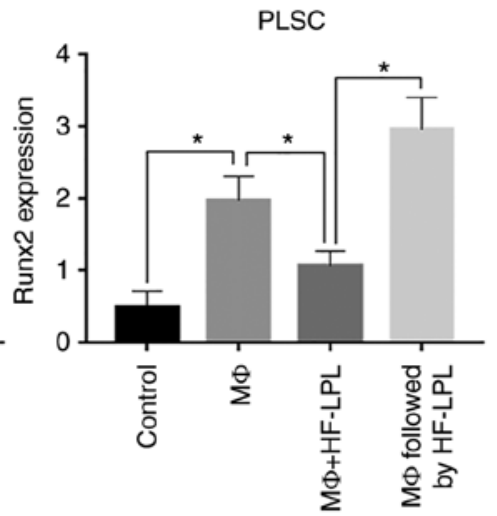

DPSC

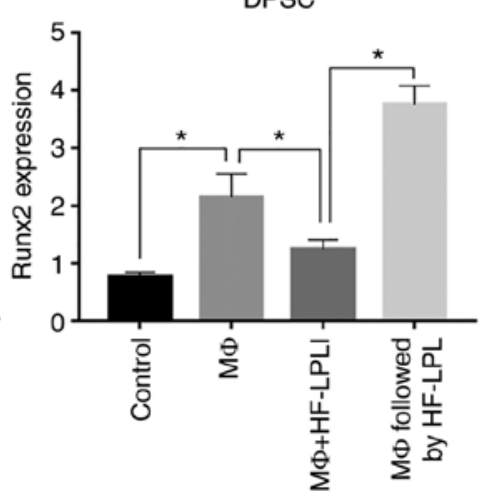

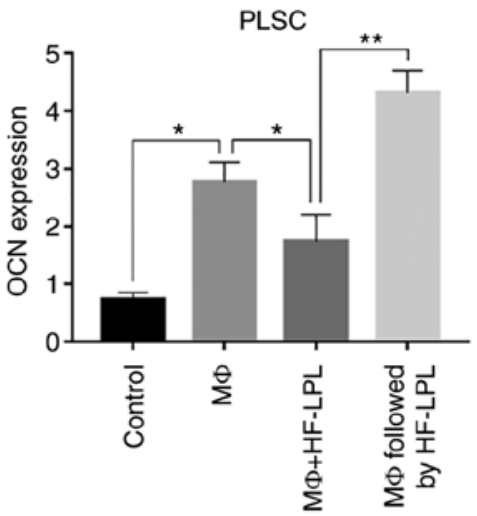

DPSC

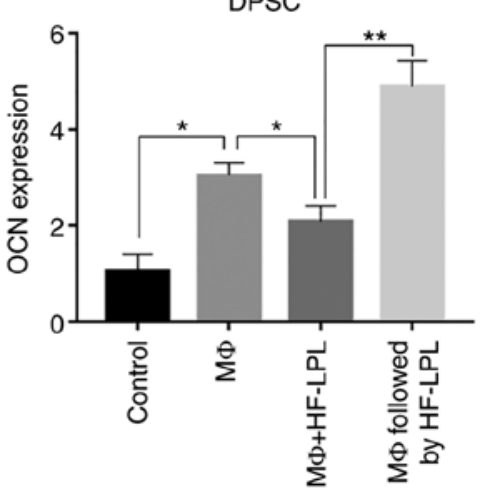

B
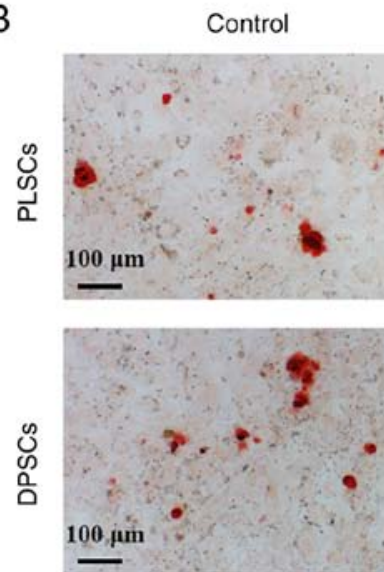

C

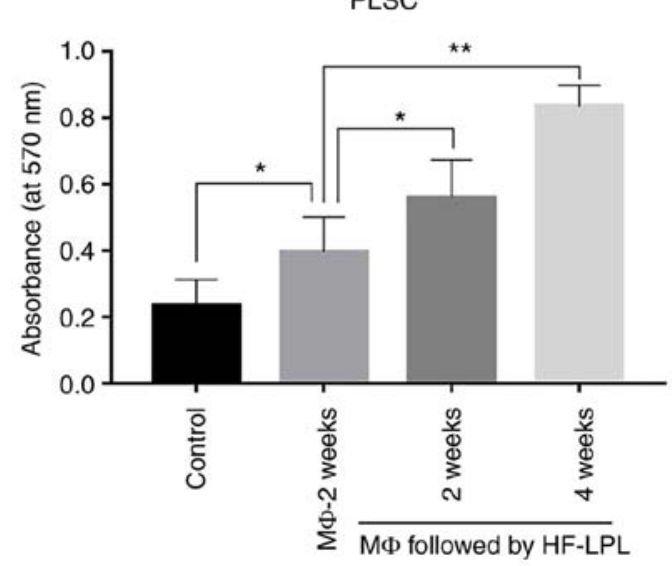

MФ-2 weeks

PLSC
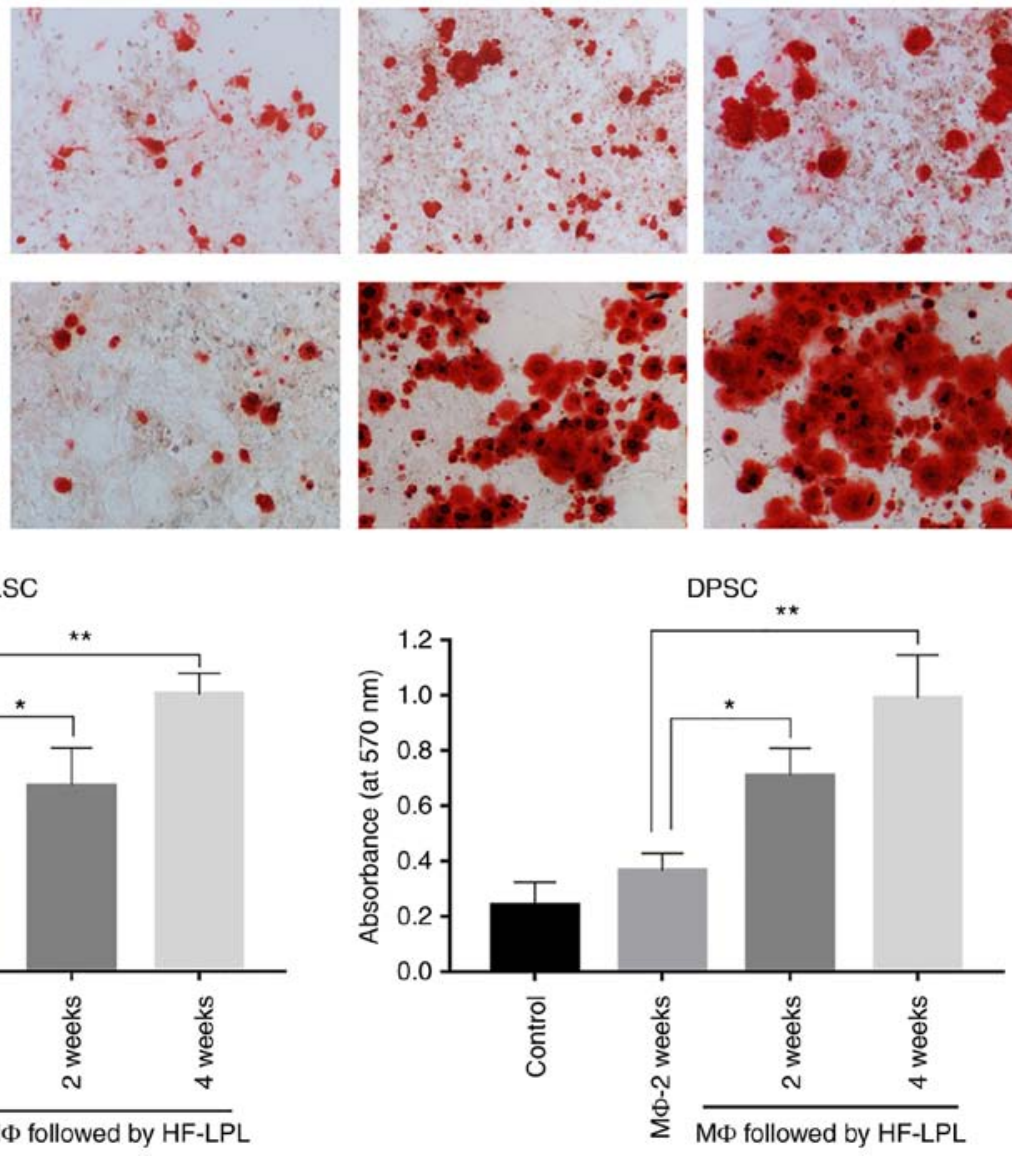

Figure 4. HF-LPLI improved stem cell odontoblastic differentiation. (A) Expression levels of ALP, OCN and Runx2 genes in stem cells, detected by reverse transcription-quantitative polymerase chain reaction. (B) Odontoblastic differentiation in stem cells, represented by the alizarin red S stained area (scale bar, $100 \mu \mathrm{m}$ ). (C) Bar graph results of alizarin red S staining at $570 \mathrm{~nm}$. ${ }^{*} \mathrm{P}<0.05$ and ${ }^{* *} \mathrm{P}<0.01$. HF-LPLI, high-frequency low-power laser irradiation; M $\Phi$, macrophage; PLSC, periodontal ligament stem cell; DPSC, dental pulp stem cell. 
A
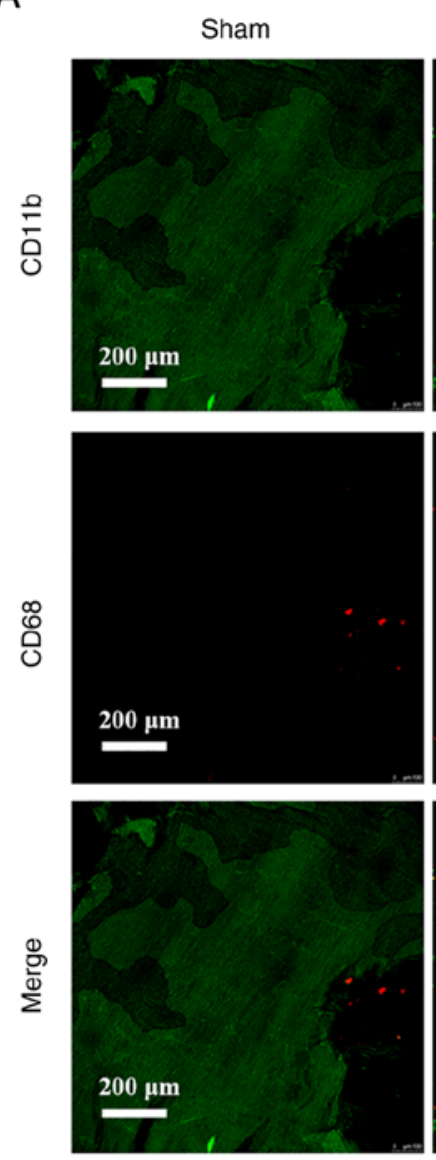

B

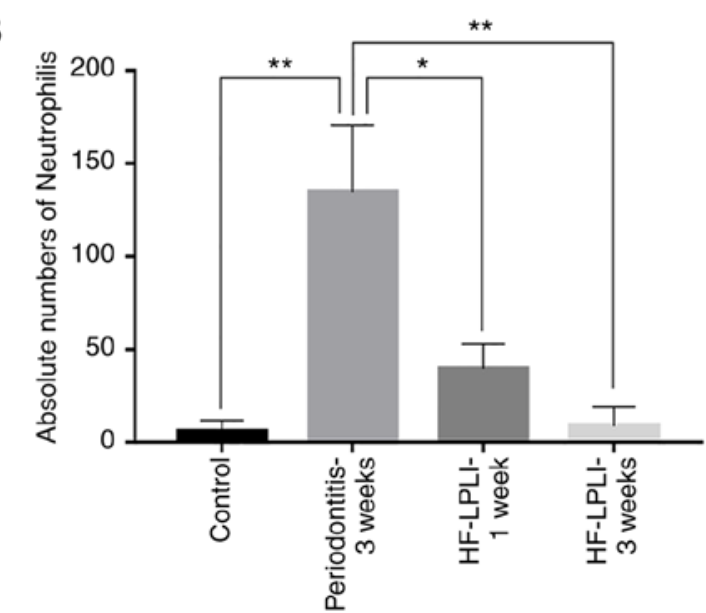

Periodontitis-3 weeks
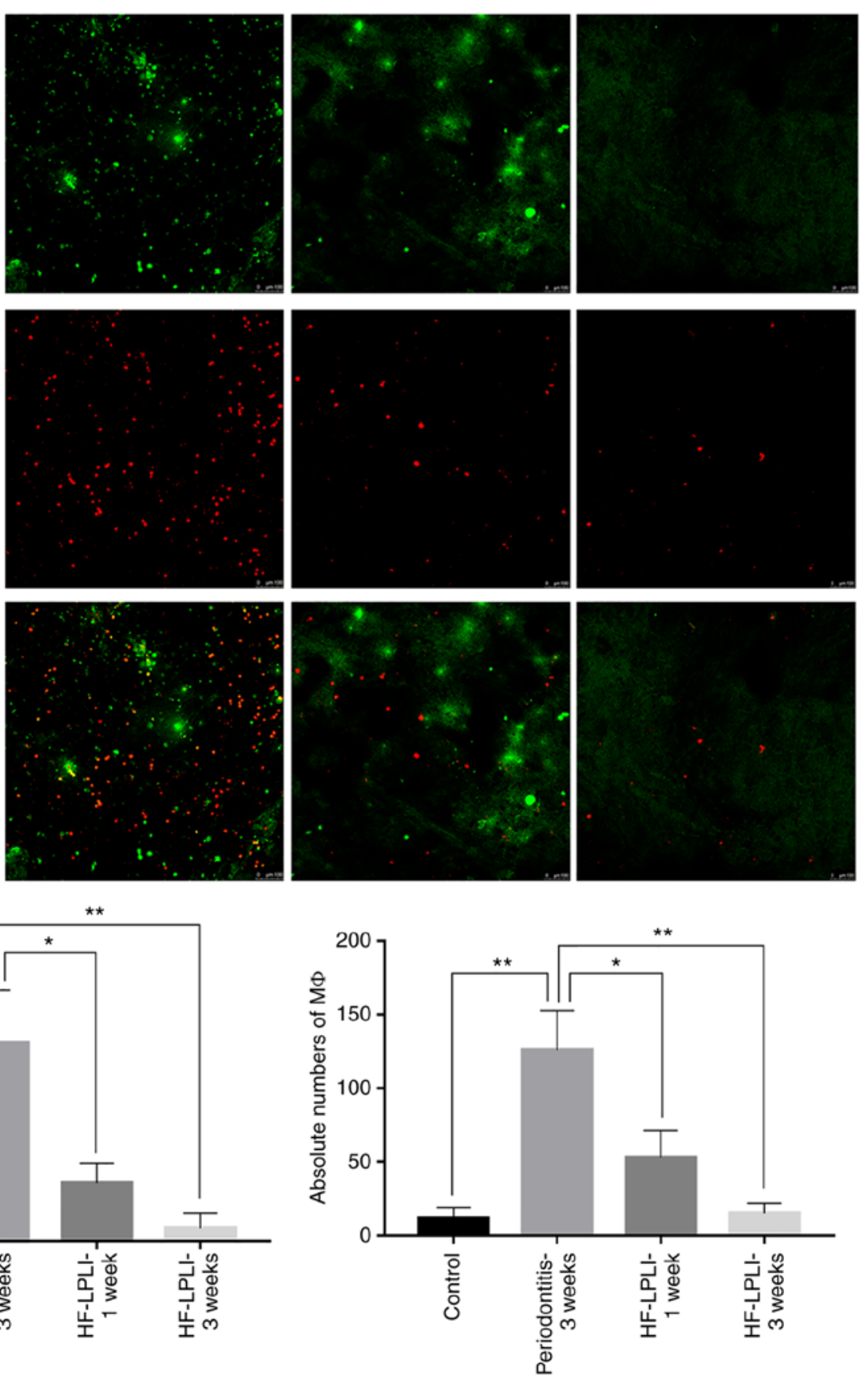

Figure 5. HF-LPLI reduced inflammatory cell infiltration in a periodontitis rat model. (A) Immunofluorescence analysis demonstrating green-stained CD11b neutrophils and red-stained CD86 macrophages (scale bar, $100 \mu \mathrm{m}$ ). (B) Bar graph of inflammatory cell number in the local periodontitis tissue in the rat model, examined by immunofluorescence. ${ }^{*} \mathrm{P}<0.05$ and ${ }^{* *} \mathrm{P}<0.01$. HF-LPLI, high-frequency low-power laser irradiation.

IL-1 $\beta$, IL-6, TNF- $\alpha$ and NO levels in the blood of rats belonging to different groups were subsequently examined, and significantly increased plasma concentrations of pro-inflammatory cytokines in rats with periodontitis were detected, as compared with the control group. The levels observed in the periodontitis rats were $173 \pm 12.6 \mathrm{pg} / \mathrm{ml}$ for IL-1 $\beta, 1,237 \pm 94.1 \mathrm{pg} / \mathrm{ml}$ for IL- $6,496 \pm 17.2 \mathrm{pg} / \mathrm{ml}$ for TNF- $\alpha$ and $0.02 \pm 0.004 \mu \mathrm{mol} / \mathrm{ml}$ for NO (Fig. 6A-D). After 1-week HF-LPLI treatment, these concentrations were significantly decreased, with IL-6 reduction to a level of $733 \pm 62.3 \mathrm{pg} / \mathrm{ml}$ representing the best result (Fig. 6B). After 3 weeks of treatment, the concentration of pro-inflammatory cytokines reached approximately the normal level. Taken together, these results indicated that appropriate HF-LPLI treatment was able to decrease the level of pro-inflammatory cytokines.

HF-LPLI induces dentin repair and tertiary dentin in a rodent model. The results were further confirmed in the animal model by evaluating the effectiveness of treating a dental defect $(3 \times 3 \times 8 \mathrm{~mm})$ with stem cells (Fig. 7A). The results 
A

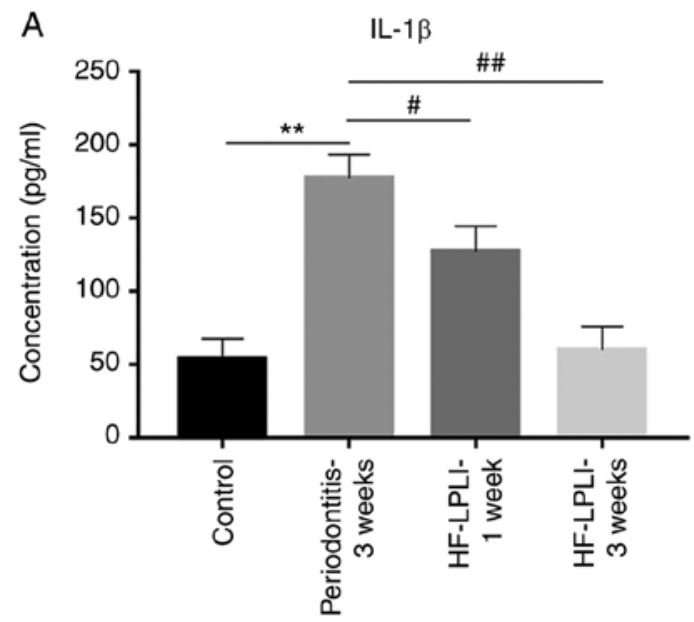

C

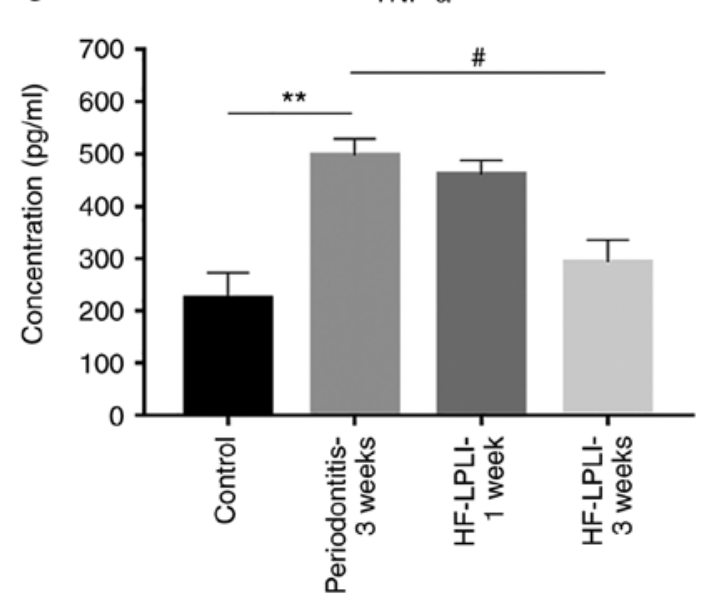

B

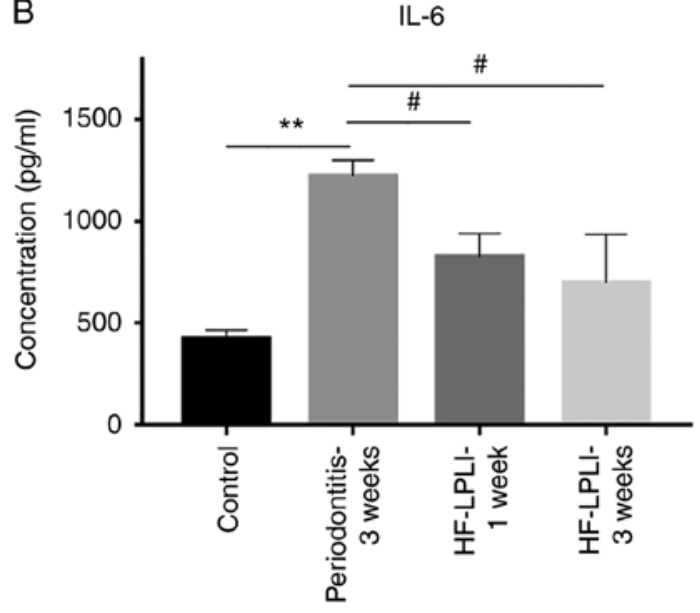

D

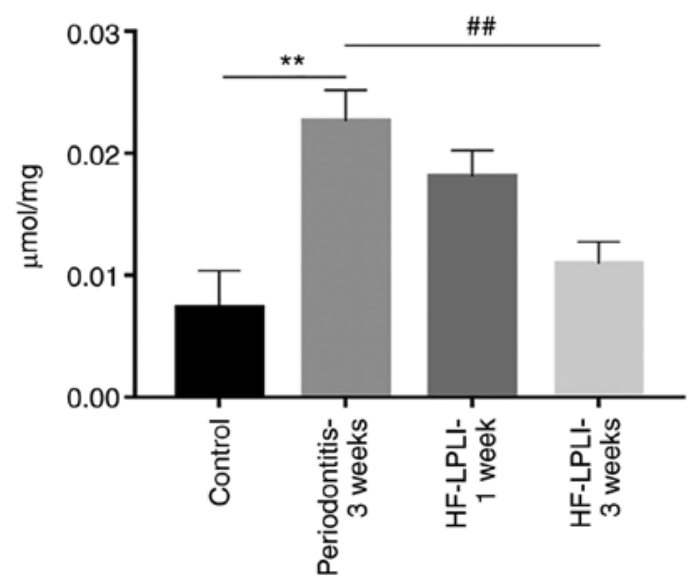

Figure 6. HF-LPLI inhibited the release of inflammatory factors in the rat model of periodontitis. (A) IL-1 $\beta$, (B) IL-6 and (C) TNF- $\alpha$ concentrations, detected by ELISA. (D) NO production determined by nitrate reductase analysis. ${ }^{* *} \mathrm{P}<0.01$ vs. periodontics 3 -weeks, ${ }^{\#} \mathrm{P}<0.05$ and ${ }^{\# \#} \mathrm{P}<0.01$ vs. the control. HF-LPLI, high-frequency low-power laser irradiation; TNF- $\alpha$, tumor necrosis factor $\alpha$; IL, interleukin; NO.

of in vivo imaging demonstrated the presence of significant inflammation in the oral cavity of the animal model, and the inflammation was reduced after 6 weeks of treatment with stem cells followed by HF-LPLI (Fig. 7B). In addition, H\&E staining results revealed that the pulp defect was successfully reconstructed in the rat model, and cell proliferation was clearly time-dependent (Fig. 7C). Calcification observed under a microscope indicated the occurrence of osteogenic differentiation. A statistically significant difference in osteogenesis was observed among the periodontitis animal model, the 6-week treatment and 12-week treatment groups $(\mathrm{P}<0.05$; Fig. 7D), suggesting that HF-LPLI treatment was effective in vivo.

\section{Discussion}

DPSCs and PLSCs have previously been used in the treatment of periodontal tissue for regeneration studies (45); however, the improvement of their therapeutic effect and the underlying mechanism of their action remain under debate. In order to identify a new strategy for the application of DPSCs and PLSCs in the treatment of periodontitis, HF-LPLI was used in the current study to induce cell orientation and to identify the potential mechanism of promoting inflamma- tion reduction by enhancing neutrophil apoptosis and MФ reprogramming.

In the experiments of the present study, HF-LPLI was found to promote neutrophil apoptosis and $\mathrm{M} \Phi$ reprogramming, which may via the inactivation of Akt/GSK3 $\beta$ signaling pathway (17). Neutrophil apoptosis reduced the inflammatory response induced by periodontitis, while the transformation of MФs reduced the secretion of pro-inflammatory cytokines and increased the release of anti-inflammatory cytokines, such as IL-10 and TGF- $\beta$. M1 MФs secrete ROS, RNS, TNF- $\alpha$, IL-1, IL-12, IL-23 and other chemokines, which are mainly involved in the inflammatory response and host immune functions, and cause inflammatory damage to normal tissues. Under the action of IL-4, IL-13, IL-10 and TGF- $\beta$, the M1 MФs are polarized to M2, which secrete TGF- $\beta$, VEGF, EGF and other factors, particularly at the late stage of inflammation, and promote the repair of trauma and fibrosis (46). Thus, the transformation of M1 to M2 can effectively promote the regression of inflammation. Notably, the current study findings reported that HF-LPLI promotes neutrophil apoptosis, but did not promote $М \Phi$ apoptosis, and the mechanism involved in this effect warrants further investigation.

This mechanism by which HF-LPLI promotes neutrophil apoptosis and $\mathrm{M} \Phi$ reprogramming led to the maintenance 
A

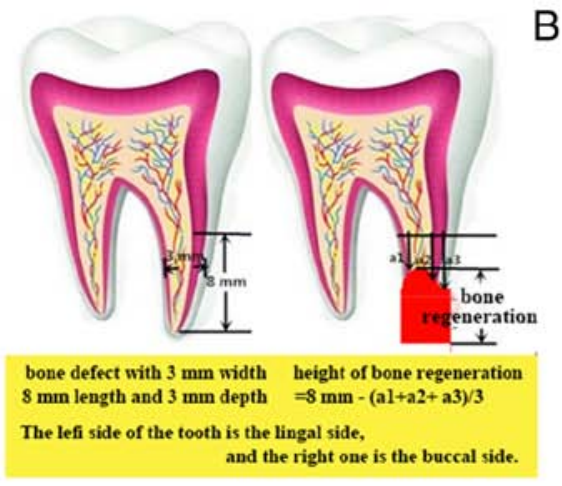

C

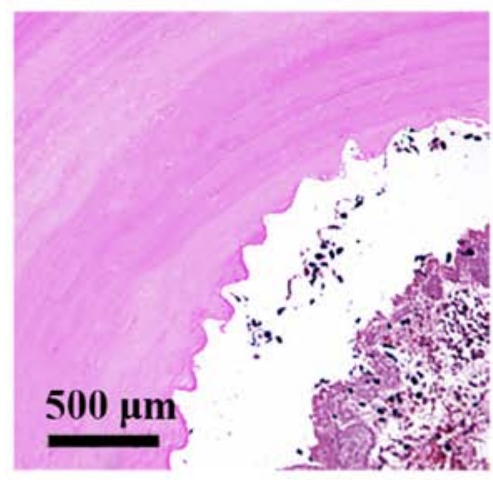

Periodontitis

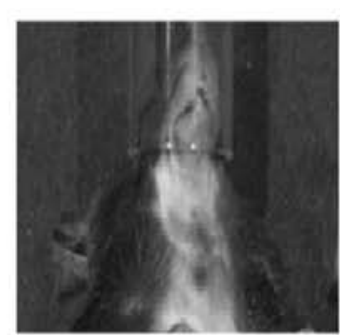

Control

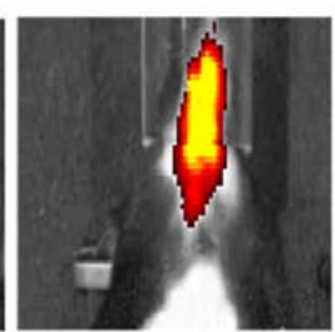

Periodontitis

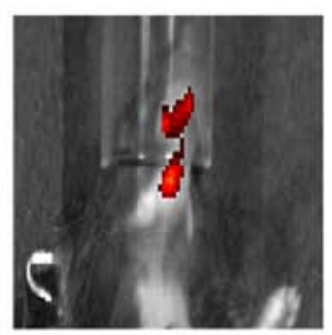

Stemcells+HF-LPLI

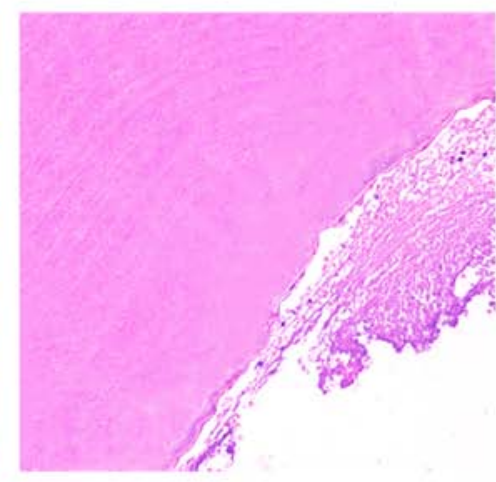

Stemcells+HF-LPLI-6 weeks

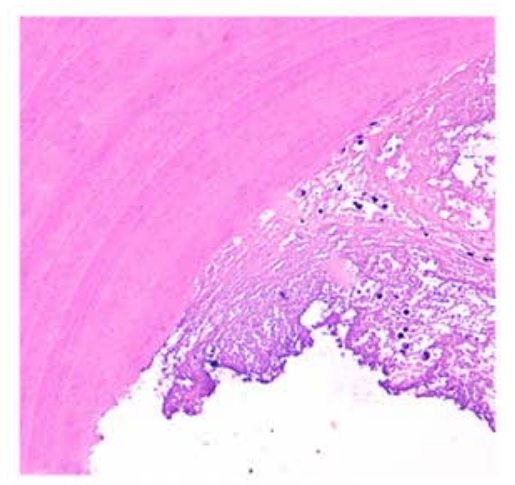

Stemcells+HF-LPLI-12 weeks

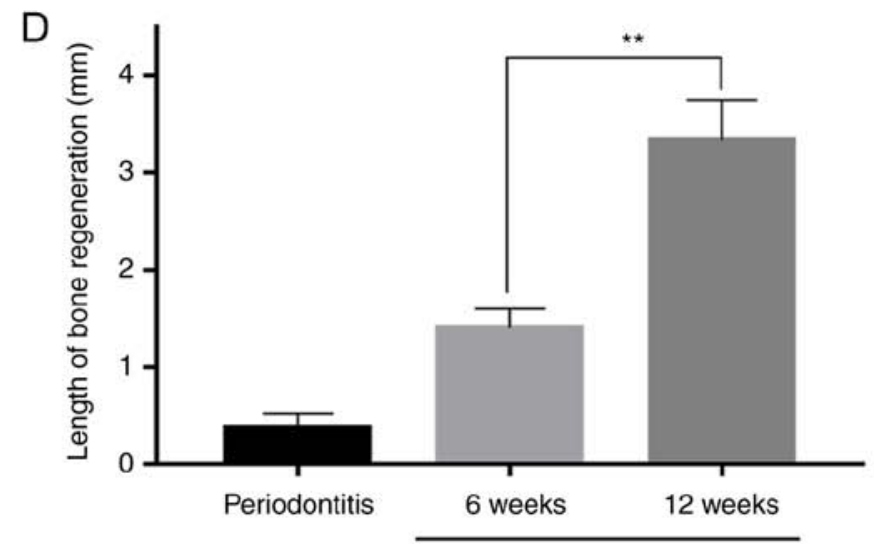

Stemcells+HF-LPLI

Figure 7. HF-LPLI induced dentin repair and tertiary dentin in the rat model of periodontitis. (A) A 3x3x8-mm pulp defect was performed in the rat model. Bone regeneration was evaluated as follows: Height of bone regeneration $=8 \mathrm{~mm}-(\mathrm{a} 1+\mathrm{a} 2+\mathrm{a} 3) / 3$. (B) Inflammation in the oral cavity of the periodontitis model, examined by in vivo bioluminescence imaging. (C) Hematoxylin and eosin staining of tissues around the focus, showing stem cell proliferation and differentiation (scale bar, $500 \mu \mathrm{m}$ ). (D) Bar graph displaying the difference in bone regeneration over time. ${ }^{* *} \mathrm{P}<0.01$. HF-LPLI, high-frequency low-power laser irradiation.

of stem cell viability and increased the expression of stemness-associated genes. The proliferation of stem cells was guaranteed at an early stage of the treatment i.e., the stemness of the cells was well maintained allowing for unhindered proliferation. These results suggested a key role of HF-LPLI in the treatment of periodontitis.

As shown by EdU proliferation assay, stem cell proliferation was not significantly different from that in M $\Phi+H F-L P L I$ simultaneously-treated groups when stem cells were co-cultured with $M \Phi$ s to create the inflammatory environment and subjected to HF-LPLI simultaneous treatment. However, when HF-LPLI treatment was applied $6 \mathrm{~h}$ after co-culture with $\mathrm{M} \Phi \mathrm{s}$, cell proliferation was signifi- cantly enhanced. These results suggested that inflammation obtained by HF-LPLI treatment for a certain period of time served a role in starting and promoting the proliferation of stem cells, while excessive inflammatory response was reduced by HF-LPLI treatment at $6 \mathrm{~h}$, improving the microenvironment and further promoting stem cell proliferation. Gene expression and alizarin red S staining demonstrated similar results, further indicating that HF-LPLI promoted differentiation following activation by appropriate inflammation. The results also revealed that M $\Phi$ followed by HF-LPLI induced a better bone differentiation at 4 weeks, particularly when DPSCs were used, which achieved a better differentiation result compared with PLSCs. 
In the in vivo experiments, after induced periodontitis was treated with stem cells, no treatment was administered to the model to induce inflammation in $6 \mathrm{~h}$. Proper inflammation promoted the proliferation of stem cells and was beneficial to subsequent differentiation. Subsequently, HF-LPLI was used to reduce the number of inflammatory cells and inhibited the release of inflammatory cytokines. The in vivo bioluminescence imaging revealed that, after 6 weeks of HF-LPLI treatment, the inflammation was reduced. As soon as inflammation was inhibited, H\&E staining indicated tissue regeneration due to stem cell proliferation, and further osteogenic differentiation. Therefore, stem cells appeared to successfully achieve periodontitis treatment. At 12 weeks, the best treatment effect was obtained, which was markedly greater than the effect at 6 weeks, suggesting a better osteogenic differentiation after an additional 6 weeks.

In conclusion, HF-LPLI may represent a novel strategy for improving the effect of stem cells treatment. However, how to use HF-LPLI for achieving the best effect in the treatment of periodontitis should be confirmed. Furthermore, the treatment dose and the time required to maximize an anti-inflammatory effect, as well as the effect of HF-LPLI on human periodontitis require additional experiments.

\section{Acknowledgements}

Not applicable.

\section{Funding}

This study was supported by grants from the National Key Research and Development Plan Young Scientists Program (no. SQ2017ZY050258), the National Science Foundation of China (nos. 31200731 and 31170935), and the Joint Research Fund for Overseas Chinese Young Scholars (no. 31028008).

\section{Availability of data and materials}

The analyzed data sets generated during the study are available from the corresponding author on reasonable request.

\section{Authors' contributions}

HY took part in all experiments and was the major contributor in writing the manuscript. XW completed the cell experiments and took part in data analysis. FK was responsible for the cell culture and part of data analysis. ZC helped complete cell experiments and other experiments in vivo. YM took part in part animal experiments and manuscript writing. MD was in charge of the overall planning and gave substantial advices for experiments and manuscript. All authors read and approved the final manuscript.

\section{Ethics approval and consent to participate}

All animal procedures were performed according to the Guide for the Care and Use of Laboratory Animals, following the ARRIVE guidelines, and were approved by the Institutional Clinical Experiments Committee of the Liaocheng People's Hospital (Liaocheng, China) and the Animal Care Committee.
All the patients included in the present study were informed of the condition and agreed to participate in the research.

\section{Patient consent for publication}

All the patients included in the present study were informed of the condition and agreed to participate in the research.

\section{Competing interests}

The authors declare that there are no conflicts of interest in connection with this article.

\section{References}

1. Cohen EE, LaMonte SJ, Erb NL, Beckman KL, Sadeghi N, Hutcheson KA, Stubblefield MD, Abbott DM, Fisher PS, Stein KD, et al: American cancer society head and neck cancer survivorship care guideline. CA Cancer J Clin 66: 203-239, 2016.

2. Katz J, Marc H, Porter S and Ruskin J: Inflammation, periodontitis, and coronary heart disease. Lancet 358: 1998, 2001.

3. Cotti E, Abramovitch K, Jensen J, Schirru E, Rice DD, Oyoyo U and Torabinejad M: The influence of adalimumab on the healing of apical periodontitis in ferrets. J Endod 43: 1841-1846, 2017.

4. Garg K, Tripathi T, Rai P, Sharma N and Kanase A: Prospective evaluation of psychosocial impact after one year of orthodontic treatment using PIDAQ adapted for indian population. J Clin Diagn Res 11: ZC44-ZC48, 2017.

5. Trupthi DV, Chowdhury S, Shah A and Singh M: Treatment of mandibular fractures using intermaxillary fixation and vacuum forming splints: A comparative study. J Maxillofac Oral Surg 13: 519-524, 2014.

6. Kl V, Ryana H and Dalvi PJ: Autologous periodontal stem cell assistance in periodontal regeneration technique (SAI-PRT) in the treatment of periodontal intrabony defects: A case report with one-year follow-up. J Dent Res Dent Clin Dent Prospects 11: 123-126, 2017.

7. Zhu X, Zhang C, Huang GT, Cheung GS, Dissanayaka WL and Zhu W: Transplantation of dental pulp stem cells and platelet-rich plasma for pulp regeneration. J Endod 38: 1604-1609, 2012.

8. Ahmed NE, Murakami M, Kaneko S and Nakashima M: The effects of hypoxia on the stemness properties of human dental pulp stem cells (DPSCs). Sci Rep 6: 35476, 2016.

9. Di Benedetto A, Carbone C and Mori G: Dental pulp stem cells isolation and osteogenic differentiation a good promise for tissue engineering. Methods Mol Biol 1210: 117-130, 2014.

10. Doan L, Kelley C, Luong H, English J, Gomez H, Johnson E, Cody D and Duke PJ: Engineered cartilage heals skull defects. Am J Orthod Dentofacial Orthop 137: 162 e1-9, 2010.

11. Cardoso EM, Reis C and Manzanares-Cespedes MC: Chronic periodontitis, inflammatory cytokines, and interrelationship with other chronic diseases. Postgrad Med 130: 98-104, 2018.

12. Klar AS, Michalak-Micka K, Biedermann T, Simmen-Meuli C, Reichmann E and Meuli M: Characterization of M1 and M2 polarization of macrophages in vascularized human dermo-epidermal skin substitutes in vivo. Pediatr Surg Int 34: 129-135, 2018.

13. Quero L, Hanser E, Manigold T, Tiaden AN and Kyburz D: TLR2 stimulation impairs anti-inflammatory activity of M2-like macrophages, generating a chimeric M1/M2 phenotype. Arthritis Res Ther 19: 245, 2017.

14. Hingert D, Barreto Henriksson H, and Brisby H: Human mesenchymal stem cells pre-treated with IL-1 $\beta$ and stimulated with BMP-3 enhance chondrogenesis. Tissue Eng Part A 24: 775-7885, 2018.

15. Rubtsov Y, Goryunov K, Romanov A, Suzdaltseva Y, Sharonov G and Tkachuk V: Molecular mechanisms of immunomodulation properties of mesenchymal stromal cells: A new insight into the role of ICAM-1. Stem Cells Int 2017: 6516854, 2017.

16. Noda M, Aoki A, Mizutani K, Lin T, Komaki M, Shibata S and Izumi Y: High-frequency pulsed low-level diode laser therapy accelerates wound healing of tooth extraction socket: An in vivo study. Lasers Surg Med 48: 955-964, 2016.

17. Huang L, Wu S and Xing D: High fluence low-power laser irradiation induces apoptosis via inactivation of Akt/GSK3 $\beta$ signaling pathway. J Cell Physiol 226: 588-601, 2011. 
18. Ferro F, Spelat R and Baheney CS: Dental pulp stem cell (DPSC) isolation, characterization, and differentiation. Methods Mol Biol 1210: 91-115, 2014.

19. Eubanks EJ, Tarle SA and Kaigler D: Tooth storage, dental pulp stem cell isolation, and clinical scale expansion without animal serum. J Endod 40: 652-657, 2014.

20. Athanassiou-Papaefthymiou M,Papagerakis $P$ and Papagerakis S: Isolation and characterization of human adult epithelial stem cells from the periodontal ligament. J Dent Res 94: 1591-1600, 2015.

21. Tran HB, Doan VN, Le HT and Ngo LT: Various methods for isolation of multipotent human periodontal ligament cells for regenerative medicine. In Vitro Cell Dev Biol Anim 50: 597-602, 2014.

22. Kawakami Y, Katayama T, Kishida M, Oda W and Inoue Y: A case of streptobacillus moniliformis infection with cutaneous leukocytoclastic vasculitis. Acta Med Okayama 70: 377-381, 2016.

23. Nakahashi-Oda C, Udayanga KG, Nakamura Y, Nakazawa Y, Totsuka N, Miki H, Iino S, Tahara-Hanaoka S, Honda S, Shibuya K and Shibuya A: Apoptotic epithelial cells control the abundance of Treg cells at barrier surfaces. Nat Immunol 17: 441-450, 2016

24. Lemos DR, Babaeijandaghi F, Low M, Chang CK, Lee ST, Fiore D, Zhang RH, Natarajan A, Nedospasov SA and Rossi FM: Nilotinib reduces muscle fibrosis in chronic muscle injury by promoting TNF-mediated apoptosis of fibro/adipogenic progenitors. Nat Med 21: 786-794, 2015.

25. Zhu Q, Tian G, Tang Z, Gao J and Tan Y: Adrenomedullin promotes the proliferation and inhibits apoptosis of dental pulp stem cells involved in divergence pathways. J Endod 42: $1347-1354,2016$

26. Jedicke N, Struever N, Aggrawal N, Welte T, Manns MP, Malek NP, Zender L, Janciauskiene $S$ and Wuestefeld T: $\alpha-1$-antitrypsin inhibits acute liver failure in mice. Hepatology 59: 2299-2308, 2014.

27. Su D, Hu X, Dong C and Ren J: Determination of caspase-3 activity and its inhibition constant by combination of fluorescence correlation spectroscopy with a microwell chip. Anal Chem 89: 9788-9796, 2017.

28. Biczo G, Vegh ET, Shalbueva N, Mareninova OA, Elperin J, Lotshaw E, Gretler S, Lugea A, Malla SR, Dawson D, et al: Mitochondrial dysfunction, through impaired autophagy, leads to endoplasmic reticulum stress, deregulated lipid metabolism, and pancreatitis in animal models. Gastroenterology 154: 689-703, 2018.

29. Wang Y, Woehrstein JB, Donoghue N, Dai M, Avendano MS, Schackmann RCJ, Zoeller JJ, Wang SSH, Tillberg PW, Park D, et al: Rapid sequential in situ multiplexing with DNA exchange imaging in neuronal cells and tissues. Nano Lett 17: 6131-6139, 2017

30. Cao Z, Duan X, Yao P, Cui W, Cheng D, Zhang J, Jin Q, Chen J, Dai $\mathrm{T}$ and Shen W: Hydrogen gas is involved in auxin-induced lateral root formation by modulating nitric oxide synthesis. Int J Mol Sci 18: E2084, 2017.

31. Yan Y, Du Y, Zheng H, Wang G, Li R, Chen J and Li K: NS1 of H7N9 Influenza a virus induces NO-mediated cellular senescence in neuro2a cells. Cell Physiol Biochem 43: 1369-1380, 2017.

32. Dolezal E, Infantino S, Drepper F, Borsig T, Singh A, Wossning T, Fiala GJ, Minguet S, Warscheid B, Tarlinton DM, et al: The BTG2-PRMT1 module limits pre-B cell expansion by regulating the CDK4-Cyclin-D3 complex. Nat Immunol 18: 911-920, 2017.

33. WolfY,Boura-Halfon S,Cortese N,HaimonZ,SarSH,Kuperman Y, Kalchenko V, Brandis A, David E, Segal-Hayoun Y, et al: Brown-adipose-tissue macrophages control tissue innervation and homeostatic energy expenditure. Nat Immunol 18: 665-674, 2017.

34. Jung JK, Gwon GJ, Neupane S, Sohn WJ, Kim KR, Kim JY, An SY, Kwon TY, An CH, Lee Y, et al: Bortezomib facilitates reparative dentin formation after pulp access cavity preparation in mouse molar. J Endod 43: 2041-2047, 2017.
35. Owen KM, Campbell PM, Feng JQ, Dechow PC and Buschang PH: Elevation of a full-thickness mucoperiosteal flap alone accelerates orthodontic tooth movement. Am J Orthod Dentofacial Orthop 152: 49-57, 2017.

36. Pereira PD, Serra-Caetano A, Cabrita M, Bekman E, Braga J, Rino J, Santus R, Filipe PL, Sousa AE and Ferreira JA: Quantification of cell cycle kinetics by EdU (5-ethynyl-2'-deox yuridine)-coupled-fluorescence-intensity analysis. Oncotarget 8 : 40514-40532, 2017.

37. Wu YC, Cheng WC, Chung MP, Su CC, Weng PW, Cathy Tsai YW, Chiang HS, Yeh HW, Chung $\mathrm{CH}$, Shieh YS and Huang RY: Complicated root canal morphology of mandibular lateral incisors is associated with the presence of distolingual root in mandibular first molars: A cone-beam computed tomographic study in a taiwanese population. J Endod 44: 73-79, 2018.

38. Sundaresan S, Meininger CA, Kang AJ, Photenhauer AL, Hayes MM, Sahoo N, Grembecka J, Cierpicki T, Ding L, Giordano TJ, et al: Gastrin induces nuclear export and proteasome degradation of menin in enteric glial cells. Gastroenterology 153: $1555-1567,2017$

39. Loosen SH, Roderburg C, Kauertz KL, Pombeiro I, Leyh C, Benz F, Vucur M, Longerich T, Koch A, Braunschweig T, et al: Elevated levels of circulating osteopontin are associated with a poor survival after resection of cholangiocarcinoma. J Hepatol 67: 749-757, 2017.

40. Tsao YT, Huang YJ, Wu HH, Liu YA, Liu YS and Lee OK: Osteocalcin mediates biomineralization during osteogenic maturation in human mesenchymal stromal cells. Int J Mol Sci 18: E159, 2017

41. Knopp KL, Stenfors C, Baastrup C, Bannon AW, Calvo M, Caspani O, Currie G, Finnerup NB, Huang W, Kennedy JD, et al: Experimental design and reporting standards for improving the internal validity of pre-clinical studies in the field of pain: Consensus of the IMI-europain consortium. Scand J Pain 7: 58-70, 2017

42. Yamaguchi H, Ishida Y, Hosomichi J, Suzuki JI, Hatano K, Usumi-Fujita R, Shimizu Y, Kaneko S and Ono T: Ultrasound microbubble-mediated transfection of NF- $\mathrm{BB}$ decoy oligodeoxynucleotide into gingival tissues inhibits periodontitis in rats in vivo. Plos One 12: e0186264, 2017.

43. Vargas-Sanchez PK, Moro MG, Santos F, Anbinder AL, Kreich E, Moraes RM, Padilha L, Kusiak C, Scomparin DX and Franco GCN: Agreement, correlation, and kinetics of the alveolar bone-loss measurement methodologies in a ligature-induced periodontitis animal model. J Appl Oral Sci 25: 490-497, 2017.

44. Silva-Dos-Santos D, Barreto-de-Albuquerque J, Guerra B, Moreira OC, Berbert LR, Ramos MT, Mascarenhas BAS, Britto C, Morrot A, Serra Villa-Verde DM, et al: Unraveling Chagas disease transmission through the oral route: Gateways to Trypanosoma cruzi infection and target tissues. PLoS Negl Trop Dis 11: e0005507, 2017

45. Aurrekoetxea M, Garcia-Gallastegui P, Irastorza I, Luzuriaga J, Uribe-Etxebarria V, Unda F and Ibarretxe G: Dental pulp stem cells as a multifaceted tool for bioengineering and the regeneration of craniomaxillofacial tissues. Front Physiol 6: 289, 2015.

46. Reales-Calderón JA, Aguilera-Montilla N, Corbí ÁL, Molero G and Gil C: Proteomic characterization of human proinflammatory M1 and anti-inflammatory M2 macrophages and their response to Candida albicans. Proteomics 14: 1503-1518, 2014.

This work is licensed under a Creative Commons Attribution-NonCommercial-NoDerivatives 4.0 International (CC BY-NC-ND 4.0) License. 